Review

\title{
Advance in Hydrothermal Bio-Oil Preparation from Lignocellulose: Effect of Raw Materials and Their Tissue Structures
}

\author{
Libo Zhang ${ }^{1, *}$, Xintong Dou ${ }^{2}$, Zhilin Yang ${ }^{1}$, Xiao Yang $^{2}$ and Xuqiang Guo ${ }^{1} \mathbb{D}$ \\ 1 College of Engineering, China University of Petroleum-Beijing at Karamay, Karamay 834000, China; \\ yzl2019015537@st.cupk.edu.cn (Z.Y.); guoxq@cup.edu.cn (X.G.) \\ 2 College of Chemical Engineering and Environment, China University of Petroleum, Beijing 102249, China; \\ douxintong@student.cup.edu.cn (X.D.); xiao.yang@student.cup.edu.cn (X.Y.) \\ * Correspondence: zhanglibo@cupk.edu.cn; Tel.: +86-0990-6633346
}

Citation: Zhang, L.; Dou, X.; Yang, Z.; Yang, X.; Guo, X. Advance in Hydrothermal Bio-Oil Preparation from Lignocellulose: Effect of Raw Materials and Their Tissue Structures. Biomass 2021, 1, 74-93.

https://doi.org/10.3390/

biomass 1020006

Academic Editor: Lasse Rosendahl

Received: 28 August 2021

Accepted: 22 October 2021

Published: 26 October 2021

Publisher's Note: MDPI stays neutral with regard to jurisdictional claims in published maps and institutional affiliations.

Copyright: () 2021 by the authors. Licensee MDPI, Basel, Switzerland. This article is an open access article distributed under the terms and conditions of the Creative Commons Attribution (CC BY) license (https:// creativecommons.org/licenses/by/ $4.0 /)$.

\begin{abstract}
The conversion of abundant forest- and agricultural-residue-based lignocellulosic materials into high-quality bio-oil by the mild hydrothermal method has great potential in the field of biomass utilization. Some excellent research on biomass hydrothermal process has been completed, including temperature, time, catalyst addition, etc. Meanwhile, some research related to the biomass raw material tissue structure has been illustrated by adopting mode components (cellulose, hemicellulose, lignin, protein, lipid, etc.) or their mixtures. The interesting fact is that although some real lignocellulose has approximate composition, their hydrothermal products and distributions show individual differences, which means the interaction within biomass raw material components tremendously affected the reaction pathway. Unfortunately, to our knowledge, there is no review article with a specific focus on the effects of raw materials and their tissue structure on the lignocellulose hydrothermal process. In this review, research progress on the effects of model and mixed cellulose/hemicellulose/lignin effects on hydrothermal products is initially summarized. Additionally, the real lignocellulosic raw materials structure effects during the thermal process are summed up. This article will inspire researchers to focus more attention on wood fiber biomass conversion into liquid fuels or high-value-added chemicals, as well as promote the development of world energy change.
\end{abstract}

Keywords: lignocellulose; hydrothermal; bio-oil component; tissue structure

\section{Introduction}

Although human beings have fully realized that using fossil energy is clearly not sustainable, the reality is that fossil fuels, coal, oil, and natural gas account for more than $80 \%$ of the world's energy needs [1]. Coal, oil, and natural gas are non-renewable, and their overexploitation will seriously lead to the depletion of resources. Besides, during the fossil energy consumption process, greenhouse gases emissions cause damage to the global environment. Therefore, it is very necessary and urgent to develop non-fossil fuel sources (biomass, geothermal, hydro, nuclear, solar, and wind [2,3]). Among the above non-fossil fuels, solar energy-derived biomass, in the form of chemical energy, shows strong advantages, including great production, wide distribution, low sulfur, low nitrogen, fast growth, and low carbon dioxide emissions. In addition, low sulfur and nitrogen contents in biomass materials could reduce emissions of greenhouse gases during their utilization process. Therefore, the development of biomass-based energy will play an important role in achieving the carbon-neutral target in China [4,5].

Generally, the utilization mode of biomass resources mainly includes the physical chemistry method represented by compression molding; the thermochemical method represented by combustion, liquefaction, gasification; and the biochemical method represented by fermentation. Among the above methods, hydrothermal liquefaction (HTL) is a 
thermochemical process in which biomass is treated under high pressure (5-20 MPa) at a moderate temperature $\left(200-374^{\circ} \mathrm{C}\right)[6,7]$. During the HTL process, biomass feedstocks undergo hydrolysis, dehydration, repolymerization, and other reactions to produce bio-oil (HT bio-oil), water-soluble products, gases, and solids with the presence of water [8-12]. As for bio-oil production from bioresources, pyrolysis is also an important method in which various steps are involved $[13,14]$. Compared with pyrolysis, HTL operating conditions are relatively mild, and raw materials do not need to be dehydrated, which reduces pretreatment and energy cost, which in turn exhibits broad application prospects. HT bio-oil has the characteristics of high energy density and is a potential liquid fuel and chemical raw material, which is of great significance to reduce diesel consumption and ease the shortage of high-quality fuel oil supply. Furthermore, HT bio-oil products, as chemicals, have also received wide attention. For example, Hossain et al. [15] concentrate antioxidant-active ingredients in tobacco-derived bio-oil for use in pharmaceutical and cosmetic industries. Wang et al. [16] have studied the performance of bio-oil as an asphalt additive to improve the bonding properties of asphalt. Zhang et al. [17] use bio-oil as an aluminum adhesive, expanding the application of bio-oils. Recently, the biorefineries concept has been summarized by De Blasio et. $[18,19]$ for the sustainable utilization of bioresources. The integration of processes allows for the reduction of transportation and energy consumption, and in the case that there is a surplus of energy produced, this can be sold or utilized for other purposes, providing more chance to produce fuels and chemicals from bioresources.

At present, most hydrothermal bio-oils are made from algae [20-22], while for some inland areas, the development of lignocellulose biomass materials (especially forestry and agricultural residues) to prepare HT bio-oil and other liquid fuels will have more practical characteristics [23]. Therefore, this paper will focus on lignocellulose upon lignocellulose HT bio-oil production.

The main research directions on bio-oil production from bioresources HTL process include temperature investigation, reaction time inspection, catalysts addition, and operation mode change (such as heating method), etc. Ravneet and Thallada [24] examined the effects of hydrothermal temperature and reaction time on HT bio-oil yield and conversion rate using castor residue as a raw material (Figure 1). The study found that the effect of temperature and reaction time on bio-oil yield was not linear. Temperature plays a more important role than reaction time from the view of bio-oil yield under the tested temperature range. Çolak and Durak, etc. [25] and some other researchers [26,27] also found the temperature is an efficient parameter for both the experiments with and without a catalyst for the hydrothermal-fluidization process.

(a)

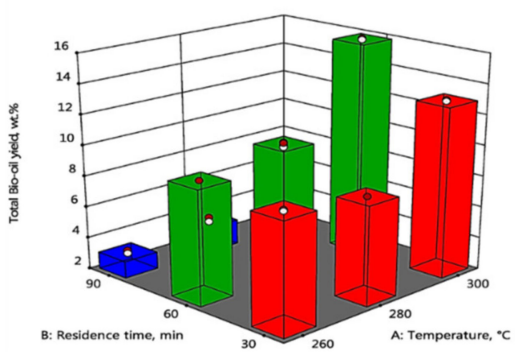

(b)

$$
\begin{aligned}
& \mathrm{X} 1=\mathrm{A}: \text { Temperature } \\
& \mathrm{X} 2=\mathrm{B}: \text { Residence tim }
\end{aligned}
$$

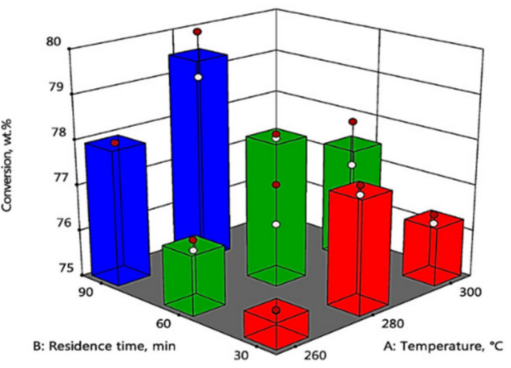

Figure 1. Effect plot of biomass conversion (a) and total bio-oil yield (b) as a function of temperature and residence time. Reprinted with permission from Ref [24]. Copyright 2019 Elsevier.

Duo and Aminul et al. [28] have found that HT bio-oil yield can be increased at lower temperatures by using oil palm fronds as raw material and ZnO/ZSM-5 as a catalyst (Figure 2). The authors believe the isomerization reaction of sugar in lignocellulose components occurs at low temperatures, and bio-oil is mainly composed of acetaldehyde. 
ZnO/ZSM-5 has the properties of both Lewis and Brønsted acid sites, which can catalyze the transformation of oil palm fruit empty string to furfural, and therefore increase the yield of HT bio-oil.

(a)

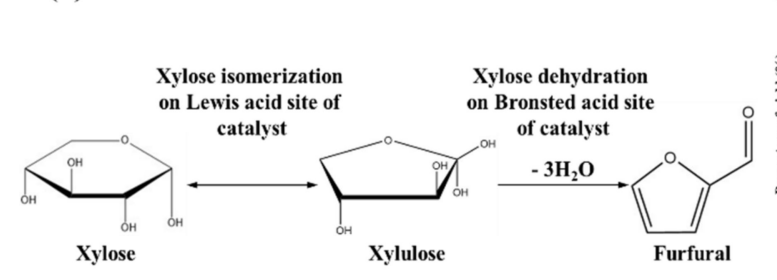

(b)

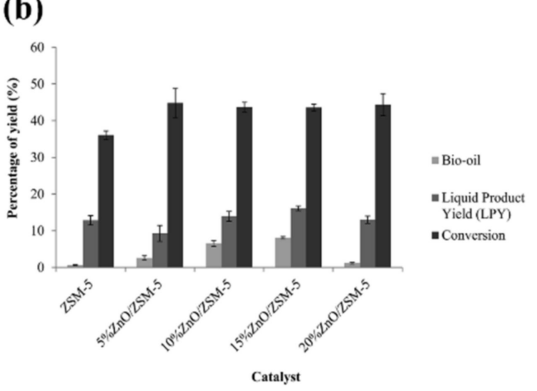

Figure 2. Effect of zinc oxide concentration on yield and proposed mechanism for biomass-derived furfural formation over ZnO-supported zeolite catalyst at $180{ }^{\circ} \mathrm{C}$. Reaction mechanism (a) and yield (b), Reprinted with permission from Ref [28]. Copyright 2017 RSC Publishing.

Microwave assistance is considered to be a promising new heating process [29-31]. Siddiqui et al. [32] demonstrate the effect of microwave radiation during the conversion process of rice shells into HT bio-oil. Results showed that microwaves promoted a more even distribution of heat in biomass feedstocks and led to higher HT bio-oil yield (Figure 3). Microwave-assisted hydrothermal oil is mainly composed of esters, phenols, ketones, aldehydes, and alcohols, which shows good application prospects.
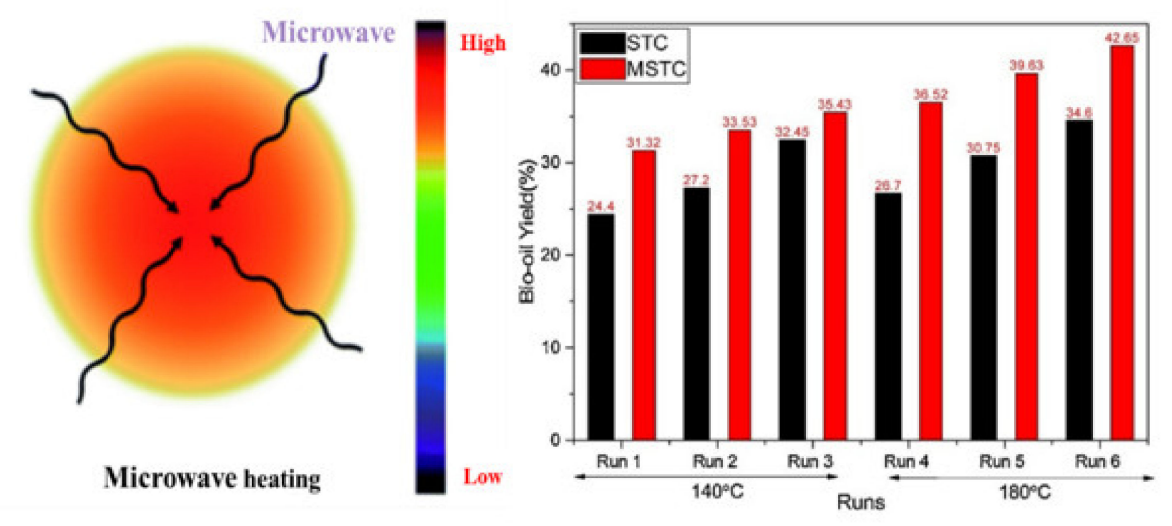

Figure 3. Microwave heating mechanism (left) and the yield of bio-oil prepared by microwaveassisted solvothermal carbonization (right). Reprinted with permission from Ref [32]. Copyright 2019 Elsevier.

Besides the microwave-assistance heating process, supercritical HTL is also very effective for lignocellulose-derived bio-oil conversion. A Norwegian-Swedish joint venture, "Silva Green Fuels", constructed an industrial hydrofaction demonstration plant in Norway with a capacity of around $4000 \mathrm{~L} /$ day [33-37]. In terms of commercial application of HTL technology, an Australian company named Muradel Pty Ltd. (Maylandscity, Western Australiastate, Australia) is a further player. This company developed a technological platform called Green2Black ${ }^{\mathrm{TM}}$, which focuses on hydrothermal integration into existing wastewater plants. The whole concept comprises several steps, including pretreatment, sub-critical $\operatorname{HTL}\left(350^{\circ} \mathrm{C}, 200 \mathrm{bar}\right)$, and upgrading and fractionation of the produced biocrude [38,39]. This company has run the "Muradel Demonstration Plant" (MDP) to realize a conversion of $60 \%$ of the organic fraction into bio-oil. Many other excellent pieces of research and reviews [40] on the biomass feedstocks hydrothermal conversion have been completed, including the addition of catalysts, the effect of operating conditions, etc. [41-45]. The operation parameters, together with biomass tissues and structure, play decisive roles during bio-oil production. Some interesting facts found are that many feedstocks contain approxi- 
mate compositions (cellulose/hemicellulose/lignin content), but their performances during conversions exhibit tremendous differences under similar operation conditions, including products yields, compounds, etc. All those differences indicate that the inherent interaction could also affect biomass feedstocks' hydrothermal process and reaction pathway. The aim of this article is to inspire researchers to pay more attention to the relation investigation between raw materials themselves and their performances during hydrothermal conversion. Firstly, the review paper introduces the structure of the plant, general hydrothermal conversion process, and product distribution of pure cellulose, hemicellulose and lignin, etc. Secondly, hydrothermal conditions, bio-oil yield, and composition from different wood fiber raw materials and the interactions between model cellulose, hemicellulose, and lignin components during hydrothermal are summarized. Finally, real biomasses and their structure effects on their HT bio-oil preparation are summed up to promote research extending into more wide raw material types. Additionally, the possibility of obtaining high HT bio-oil yield with high quality under relatively mild operation parameters by adjusting the raw materials' tissues structures is also encouraged.

\section{Structure of Lignocelluloses and Their Hydrothermal Liquefaction Mechanism}

\subsection{Structure of Plants}

Plant cell walls exhibit a multi-layered structure; the middle lamella and primary cell wall are overlaid by three layers of secondary cell walls (SCW) named S1, S2, and S3. S2 is the thickest (Figure 4), which is a determinant of the plant's mechanical property together with S1 and S2 [46-51]. The "middle lamella" between the primary cell wall and the secondary cell wall is not actually a layer in the physical sense, but some filling material (tannin and other components). The main components of the secondary cell wall are cellulose, hemicellulose, and lignin, all of which are called lignocellulose, accounting for more than $95 \%$ of the dry weight of the cell wall [49].

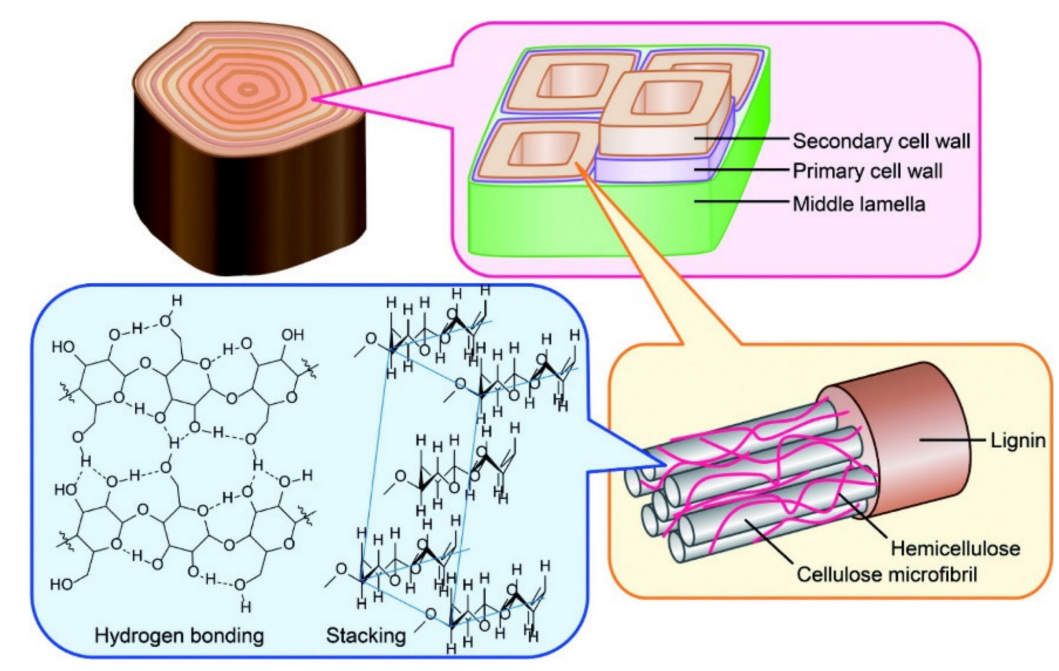

Figure 4. Schematic dia gram of cell wall structure of wood fiber. Reprinted with permission from Ref [51]. Copyright 2018 The Chemical Society of Japan.

In the S2 layer, cellulose functions as a basic skeleton (30-50 wt.\%), lignin acts as the filler (5-30 wt.\%), and hemicellulose (10-40 wt.\%) acts as an adhesive to combine lignin and cellulose. It is generally believed that four cellulose chains constitute "original fine fibers". Four primary microfibers form a "microfiber", four microfibers form a "fine fiber", and the stratification structure of the cell wall is demonstrated in Figure 4 [51].

\subsection{Hydrothermal Process and Product Distribution of Cellulose, Hemicellulose, and Lignin}

As shown in Figure 5 [52], lignocellulose mainly contains lipids, proteins, carbohydrates (cellulose and hemicellulose), and lignin [53,54]. Under hydrothermal conditions, hydrolysis, degradation, reaggregation, and the Maillard reaction occur. Among those 
reactions, lipids components are first hydrolyzed into fatty acids and glycerol and further converted into aldehyde compounds. Proteins are hydrolyzed into amino acids, and organic acids are further converted into amides. Cellulose and hemicellulose are hydrolyzed into monosaccharides (glucose, xylitol, etc.) and then converted into ketones, acids, and alcohols. Along with the further temperature increase, oxygen-containing cyclic compounds are formed directly (or through furans). Lignin, on the other hand, produces phenolic substances, mainly through hydrolysis reactions. In the actual liquefaction process, there will also be interactions between intermediate degradation products, making the composition of liquefaction products more complex. We know from Figure 5 that under low temperature $\left(<260^{\circ} \mathrm{C}\right)$, the lipids, proteins, carbohydrates (cellulose and hemicellulose), and lignin exhibit activities. In most research, the adopted hydrothermal temperatures are above $300{ }^{\circ} \mathrm{C}$ to achieve high bio-oil yield (as shown in Table 1). Thus, the possibility of obtaining a high yield will be an interesting topic for biomass hydrothermal conversion.

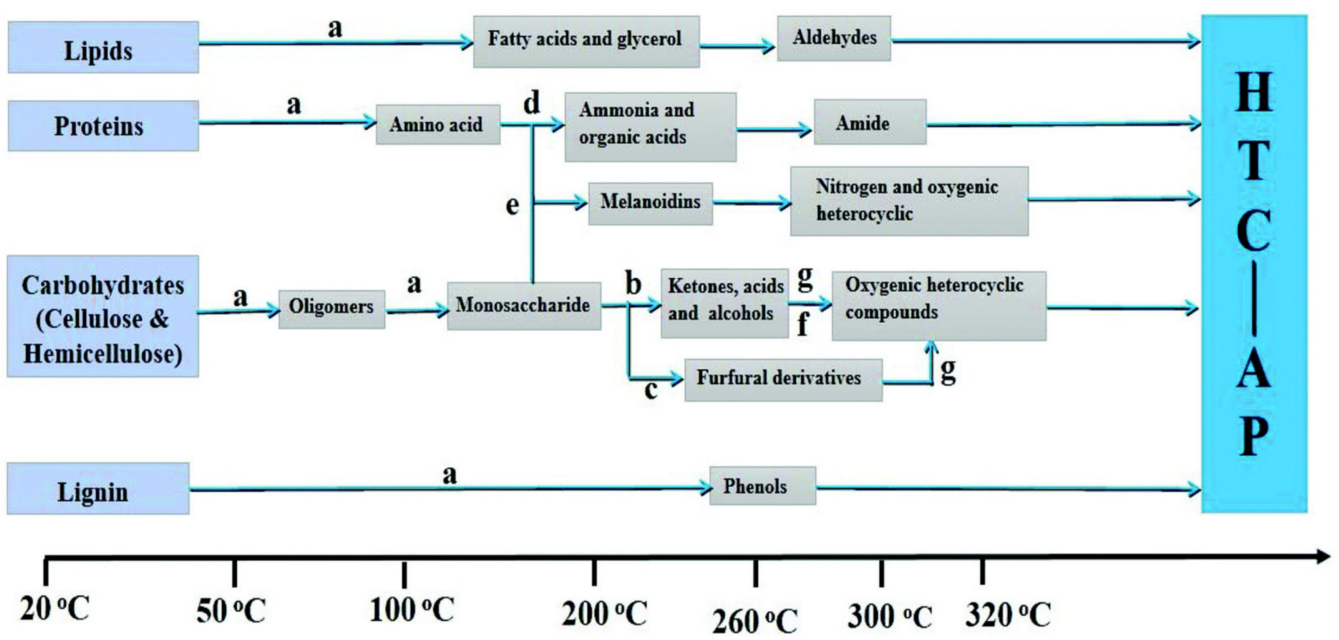

Figure 5. Reaction pathways and corresponding products of different biological structures in biomass for HTC where (a) refers to hydrolysis, (b) refers to the decomposition reaction, (c) refers to dehydration, (d) refers to deamination, (e) refers to the Maillard reaction, (f) refers to decarboxylation, and (g) refers to the cyclization reaction. Reprinted with permission from Ref [52]. Copyright 2019 RSC Publishing.

Table 1. Hydrothermal conditions, bio-oil yield, and composition of different wood fiber raw materials.

\begin{tabular}{|c|c|c|c|c|c|c|c|}
\hline Feedstock & $\begin{array}{l}\text { Feedstock Composition or Element } \\
\text { Composition (wt. } \% \text { ) }\end{array}$ & $\begin{array}{l}\text { Operating } \\
\text { Conditions }\end{array}$ & $\begin{array}{l}\text { Solid-Liquid } \\
\text { Mass Ratio }\end{array}$ & Catalyst & $\begin{array}{l}\text { Bio-Oil Yield } \\
\text { (wt.\%) }\end{array}$ & $\begin{array}{l}\text { Main Components of } \\
\text { Bio-Oil }\end{array}$ & Ref. \\
\hline Softwood & $\begin{array}{c}\text { Lignin } 28.2 \% \text {, polysaccharide } \\
70.6 \% \pm \text { (including } 64.8 \% \text { glucose, } \\
24.5 \% \text { mannose and arabinose, } \\
6.6 \% \text { xylose, and } 4.1 \% \text { galactose) }\end{array}$ & $270^{\circ} \mathrm{C}, 30 \mathrm{~min}$ & $14: 62.5$ & $\mathrm{Na}_{2} \mathrm{CO}_{3}$ & $7.4 \%$ & $\begin{array}{l}\text { Sugars, furans, organic } \\
\text { acids, and phenolic }\end{array}$ & [55] \\
\hline $\begin{array}{l}\text { Coffee } \\
\text { grounds }\end{array}$ & $\begin{array}{l}\text { Volatile matter } 82.3 \% \text {, ash } 1.4 \% \text {, } \\
\text { moisture } 4.0 \%, \text { C } 50.4 \%, \text { H } 7.2 \% \text {, } \\
\text { N } 2.1 \% \text {, O } 40.3 \%\end{array}$ & $275^{\circ} \mathrm{C}, 10 \mathrm{~min}$ & $1: 20$ & / & $43.7 \%$ & $\begin{array}{l}\text { Long-chain aliphatic acids } \\
\text { and esters }\end{array}$ & [56] \\
\hline $\begin{array}{c}\text { Water } \\
\text { hyacinth }\end{array}$ & $\begin{array}{l}\text { Moisture } 9.54 \% \text {, ash } 21.80, \\
\text { volatile } 77.85 \% \text {, fixed carbon } 0.35 \%\end{array}$ & $280^{\circ} \mathrm{C}, 15 \mathrm{~min}$ & $1: 6$ & $\mathrm{KOH}$ & $23 \%$ & Aliphatic and aromatic & [57] \\
\hline Pinus & $\begin{array}{c}\text { Branches: cellulose } 26.9 \% \text {, } \\
\text { hemicellulose } 20.8 \% \text {, lignin } 16.8 \% \text {, } \\
\text { ash } 2.8 \% \text {, ethanol extract } 7.0 \% \text {, } \\
\text { others } 25.7 \% \text {; Leaves: cellulose } 22.9 \% \text {, } \\
\text { hemicellulose } 15.0 \% \text {, lignin } 31.0 \% \text {, } \\
\text { ash } 1.3 \% \text {, ethanol extract } 8.5 \% \text {, } \\
\text { others } 21.4 \%\end{array}$ & $300^{\circ} \mathrm{C}, 30 \mathrm{~min}$ & $1: 10$ & / & $\begin{array}{c}29 \% \\
\text { (Branches), } \\
20 \% \text { (Leaves) }\end{array}$ & $\begin{array}{l}\text { Branches: phenols, } \\
\text { aliphatics, esters, acids, } \\
\text { ketones, alcohols, and } \\
\text { furans; Leaves: phenols, } \\
\text { cyclones, ketones, } \\
\text { and alcohols }\end{array}$ & {$[58]$} \\
\hline $\begin{array}{l}\text { Cupressus } \\
\text { funebris }\end{array}$ & $\begin{array}{c}\text { Branches: cellulose } 23.0 \% \text {, } \\
\text { hemicellulose } 19.0 \% \text {, lignin } 18.3 \% \text {, } \\
\text { ash } 2.9 \% \text {, ethanol extract } 5.9 \% \text {, } \\
\text { others } 31.0 \% \text {; Leaves: cellulose } 24.8 \% \text {, } \\
\text { hemicellulose } 16.9 \% \text {, lignin } 16.8 \% \text {, } \\
\text { ash } 7.4 \% \text {, ethanol extract } 8.5 \% \text {, } \\
\text { others } 25.6 \%\end{array}$ & $300^{\circ} \mathrm{C}, 30 \mathrm{~min}$ & $1: 10$ & / & $\begin{array}{c}28 \% \\
\text { (Branches), } \\
19 \% \text { (Leaves) }\end{array}$ & $\begin{array}{l}\text { Branches: phenols, } \\
\text { aliphatics, esters, acids, } \\
\text { ketones, alcohols, and } \\
\text { furans; Leaves: phenols, } \\
\text { cyclones, ketones, } \\
\text { and alcohols }\end{array}$ & [58] \\
\hline
\end{tabular}


Table 1. Cont

\begin{tabular}{|c|c|c|c|c|c|c|c|}
\hline Feedstock & $\begin{array}{l}\text { Feedstock Composition or Element } \\
\text { Composition (wt.\%) }\end{array}$ & $\begin{array}{l}\text { Operating } \\
\text { Conditions }\end{array}$ & $\begin{array}{l}\text { Solid-Liquid } \\
\text { Mass Ratio }\end{array}$ & Catalyst & $\begin{array}{l}\text { Bio-Oil Yield } \\
\quad \text { (wt.\%) }\end{array}$ & $\begin{array}{c}\text { Main Components of } \\
\text { Bio-Oil }\end{array}$ & Ref. \\
\hline Platanus & $\begin{array}{c}\text { Branches: cellulose } 27.7 \% \text {, } \\
\text { hemicellulose } 19.9 \% \text {, lignin } 18.3 \% \text {, } \\
\text { ash } 2.1 \% \text {, ethanol extract } 2.6 \% \text {, others } \\
22.1 \% \text {; Leaves: cellulose } 22.7 \% \text {, } \\
\text { hemicellulose } 16.1 \% \text {, lignin } 23.6 \% \text {, } \\
\text { ash } 6.0 \% \text {, ethanol extract } 5.4 \% \text {, } \\
\text { others } 26.3 \%\end{array}$ & $300^{\circ} \mathrm{C}, 30 \mathrm{~min}$ & $1: 10$ & / & $\begin{array}{c}29 \% \\
\text { (Branches), } \\
19 \% \text { (Leaves) }\end{array}$ & $\begin{array}{l}\text { Branches: phenols, } \\
\text { aliphatics, esters, acids, } \\
\text { ketones, alcohols, and } \\
\text { furans; Leaves: phenols, } \\
\text { cyclones, ketones, } \\
\text { and alcohols }\end{array}$ & [58] \\
\hline $\begin{array}{l}\text { Cinnamomum } \\
\text { camphora }\end{array}$ & $\begin{array}{c}\text { Branches: cellulose } 27.8 \% \text {, } \\
\text { hemicellulose } 18.4 \% \text {, lignin } 27.7 \% \text {, } \\
\text { ash } 2.0 \% \text {, ethanol extract } 4.9 \% \text {, } \\
\text { others } 19.2 \% \text {; Leaves: cellulose } 23.5 \% \text {, } \\
\text { hemicellulose } 12.9 \% \text {, lignin } 16.8 \% \text {, } \\
\text { ash } 8.0 \% \text {, ethanol extract } 5.4 \% \text {, } \\
\text { others } 33.5 \%\end{array}$ & $300^{\circ} \mathrm{C}, 30 \mathrm{~min}$ & $1: 10$ & / & $\begin{array}{c}32 \% \\
\text { (Branches) } \\
26 \% \text { (Leaves) }\end{array}$ & $\begin{array}{l}\text { Branches: phenols, } \\
\text { aliphatics, esters, acids, } \\
\text { ketones, alcohols, and } \\
\text { furans; Leaves: phenols, } \\
\text { cyclones, ketones, } \\
\text { and alcohols }\end{array}$ & [58] \\
\hline $\begin{array}{l}\text { Pittosporum } \\
\text { tobira }\end{array}$ & $\begin{array}{c}\text { Branches: cellulose } 26.7 \% \text {, } \\
\text { hemicellulose } 21.2 \% \text {, lignin } 14.5 \% \text {, } \\
\text { ash } 5.4 \% \text {, ethanol extract } 5.6 \% \text {, } \\
\text { others } 26.6 \% \text {; Leaves: cellulose } 18.2 \% \text {, } \\
\text { hemicellulose } 17.6 \% \text {, lignin } 10.6 \% \text {, } \\
\text { ash } 10.7 \% \text {, ethanol extract } 9.1 \% \text {, } \\
\text { others } 33.8 \%\end{array}$ & $300^{\circ} \mathrm{C}, 30 \mathrm{~min}$ & $1: 10$ & / & $\begin{array}{c}30 \% \\
\text { (Branches), } \\
21 \% \text { (Leaves) }\end{array}$ & $\begin{array}{l}\text { Branches: phenols, } \\
\text { aliphatics, esters, acids, } \\
\text { ketones, alcohols, and } \\
\text { furans; Leaves: phenols, } \\
\text { cyclones, ketones, } \\
\text { and alcohols }\end{array}$ & [58] \\
\hline $\begin{array}{l}\text { Distylium } \\
\text { racemosum }\end{array}$ & $\begin{array}{c}\text { Branches: cellulose } 24.5 \% \text {, } \\
\text { hemicellulose } 16.4 \% \text {, lignin } 23.1 \% \text {, } \\
\text { ash } 4.6 \% \text {, ethanol extract } 4.5 \% \text {, } \\
\text { others } 26.9 \% \text {; Leaves: cellulose } 23.7 \% \text {, } \\
\text { hemicellulose } 16.3 \% \text {, lignin } 23.8 \% \text {, } \\
\text { ash } 10.0 \% \text {, ethanol extract } 6.1 \% \text {, } \\
\text { others } 20.1 \%\end{array}$ & $300^{\circ} \mathrm{C}, 30 \mathrm{~min}$ & $1: 10$ & / & $\begin{array}{c}28 \% \\
\text { (Branches), } \\
22 \% \text { (Leaves) }\end{array}$ & $\begin{array}{l}\text { Branches: phenols, } \\
\text { aliphatics, esters, acids, } \\
\text { ketones, alcohols, and } \\
\text { furans; Leaves: phenols, } \\
\text { cyclones, ketones, } \\
\text { and alcohols }\end{array}$ & [58] \\
\hline $\begin{array}{l}\text { Viburnum } \\
\text { odoratiss- } \\
\text { inum }\end{array}$ & $\begin{array}{c}\text { Branches: cellulose } 25.4 \% \text {, } \\
\text { hemicellulose } 18.9 \% \text {, lignin } 30.1 \% \text {, } \\
\text { ash } 2.2 \% \text {, ethanol extract } 3.4 \% \text {, } \\
\text { others } 19.9 \% \text {; Leaves: cellulose } 8.3 \% \text {, } \\
\text { hemicellulose } 17.5 \% \text {, lignin } 20.1 \% \text {, } \\
\text { ash } 9.8 \% \text {, ethanol extract } 8.1 \% \text {, } \\
\text { others } 36.2 \%\end{array}$ & $300^{\circ} \mathrm{C}, 30 \mathrm{~min}$ & $1: 10$ & / & $\begin{array}{c}25 \% \\
\text { (Branches), } \\
16 \% \text { (Leaves) }\end{array}$ & $\begin{array}{l}\text { Branches: phenols, } \\
\text { aliphatics, esters, acids, } \\
\text { ketones, alcohols, and } \\
\text { furans; Leaves: phenols, } \\
\text { cyclones, ketones, } \\
\text { and alcohols }\end{array}$ & [58] \\
\hline $\begin{array}{c}\text { Salix } \\
\text { babylonica }\end{array}$ & $\begin{array}{c}\text { Branches: cellulose } 25.9 \% \text {, } \\
\text { hemicellulose } 17.0 \% \text {, lignin } 30.1 \% \text {, } \\
\text { ash } 1.4 \% \text {, ethanol extract } 3.8 \% \text {, } \\
\text { others } 21.9 \% \text {; Leaves: cellulose } 23.2 \% \text {, } \\
\text { hemicellulose } 17.3 \% \text {, lignin } 18.3 \% \text {, } \\
\text { ash } 8.8 \% \text {, ethanol extract } 4.9 \% \text {, } \\
\text { others } 27.6 \%\end{array}$ & $300^{\circ} \mathrm{C}, 30 \mathrm{~min}$ & $1: 10$ & / & $\begin{array}{c}24 \% \\
\text { (Branches), } \\
14 \% \text { (Leaves) }\end{array}$ & $\begin{array}{l}\text { Branches: phenols, } \\
\text { aliphatics, esters, acids, } \\
\text { ketones, alcohols, and } \\
\text { furans; Leaves: phenols, } \\
\text { cyclones, ketones, } \\
\text { and alcohols }\end{array}$ & [58] \\
\hline Poplar & $\begin{array}{c}\text { N } 0.91 \%, \text { C } 47.04 \%, \text { H } 5.60 \% \text {, } \\
\text { O } 43.20 \%\end{array}$ & $260^{\circ} \mathrm{C}, 30 \mathrm{~min}$ & $1: 10$ & / & $13 \%$ & $\begin{array}{l}\text { Alcohols, ethers, lipids, } \\
\text { alkanes, aldehydes, } \\
\text { and phenols }\end{array}$ & [43] \\
\hline $\begin{array}{l}\text { Oil palm } \\
\text { empty fruit } \\
\text { bunch }\end{array}$ & $\begin{array}{c}\text { Moisture } 8.99 \% \text {, dry matter } 91.01 \% \text {, } \\
\text { ash } 2.42 \% \text {, hemicellulose } 41.32 \% \text {, } \\
\text { cellulose } 39.07 \% \text {, lignin } 34.82 \% \text {, } \\
\text { C } 45.44 \% \text {, H } 6.22 \% \text {, N } 1.58 \% \text {, S } 0.36 \% \text {, } \\
\text { O } 46.40 \%\end{array}$ & $180^{\circ} \mathrm{C}, 90 \mathrm{~min}$ & $1: 10$ & $\begin{array}{c}\text { Zn/ } \\
\text { ZSM-5 }\end{array}$ & $43.6 \%$ & $\begin{array}{l}\text { Furfural, ketones, } \\
\text { aldehydes, phenol, } \\
\text { benzoic acid, and other } \\
\text { aromatic hydrocarbons }\end{array}$ & [28] \\
\hline Walnut shell & $\begin{array}{c}\text { Moisture } 5-12 \% \text {, ash } 1.5 \% \text {, cellulose } \\
23.3 \% \text {, hemicellulose } 20.4 \% \text {, lignin } \\
53.5 \% \text {, extract } 2.8 \% \text {, C } 45.6 \% \text {, H } 4.3 \% \text {, } \\
\text { O } 50.1 \%\end{array}$ & $320^{\circ} \mathrm{C}, 30 \mathrm{~min}$ & $1: 5$ & / & $25 \%$ & $\begin{array}{l}\text { Phenols, alcohols, ketones, } \\
\text { aldehydes, and phenol }\end{array}$ & [59] \\
\hline Corn straw & $\begin{array}{c}\text { Ash } 7.00 \% \text {, volatile } 68.50 \% \text {, fixed } \\
\text { carbon } 24.50 \% \text {, cellulose } 30.81 \% \text {, } \\
\text { hemicellulose } 25.52 \% \text {, lignin } 16.76 \%\end{array}$ & $320^{\circ} \mathrm{C}, 60 \mathrm{~min}$ & $3: 8$ & / & $7.9 \%$ & $\begin{array}{c}\text { Phenols, ketones, } \\
\text { aldehydes, carboxylic } \\
\text { acids, nitrogen-containing } \\
\text { heterocyclic compounds, } \\
\text { ethanol, and aromatic } \\
\text { compounds }\end{array}$ & [60] \\
\hline $\begin{array}{l}\text { Soybean } \\
\text { straw }\end{array}$ & $\begin{array}{c}\text { Ash } 4.43 \% \text {, volatile } 73.10 \% \text {, fixed } \\
\text { carbon } 22.47 \% \text {, cellulose } 42.39 \% \text {, } \\
\text { hemicellulose } 22.05 \% \text {, lignin } 18.93 \%\end{array}$ & $320^{\circ} \mathrm{C}, 60 \mathrm{~min}$ & $3: 8$ & / & $15.8 \%$ & $\begin{array}{c}\text { Phenols, ketones, } \\
\text { aldehydes, carboxylic } \\
\text { acids, nitrogen-containing } \\
\text { heterocyclic compounds, } \\
\text { and olefins }\end{array}$ & [60] \\
\hline Peanut straw & $\begin{array}{c}\text { Ash } 13.05 \% \text {, volatile } 65.50 \% \text {, fixed } \\
\text { carbon } 21.45 \% \text {, cellulose } 36.56 \% \text {, } \\
\text { hemicellulose } 20.27 \% \text {, lignin } 18.36 \%\end{array}$ & $320^{\circ} \mathrm{C}, 60 \mathrm{~min}$ & $3: 8$ & / & $14.6 \%$ & $\begin{array}{c}\text { Phenols, ketones, } \\
\text { aldehydes, carboxylic } \\
\text { acids, nitrogen-containing } \\
\text { heterocyclic compounds, } \\
\text { ethanol, alkanes, } \\
\text { and olefins }\end{array}$ & [60] \\
\hline
\end{tabular}


Table 1. Cont.

\begin{tabular}{|c|c|c|c|c|c|c|c|}
\hline Feedstock & $\begin{array}{c}\text { Feedstock Composition or Element } \\
\text { Composition (wt.\%) }\end{array}$ & $\begin{array}{l}\text { Operating } \\
\text { Conditions }\end{array}$ & $\begin{array}{l}\text { Solid-Liquid } \\
\text { Mass Ratio }\end{array}$ & Catalyst & $\begin{array}{l}\text { Bio-Oil Yield } \\
\text { (wt.\%) }\end{array}$ & $\begin{array}{l}\text { Main Components of } \\
\text { Bio-Oil }\end{array}$ & Ref. \\
\hline Rice straw & $\begin{array}{c}\text { Ash } 15.10 \% \text {, volatile } 64.00 \% \text {, fixed } \\
\text { carbon } 20.91 \% \text {, cellulose } 46.33 \% \text {, } \\
\text { hemicellulose } 31.09 \% \text {, lignin } 10.17 \%\end{array}$ & $320^{\circ} \mathrm{C}, 60 \mathrm{~min}$ & $3: 8$ & / & $15.1 \%$ & $\begin{array}{c}\text { Phenols, ketones, } \\
\text { aldehydes, carboxylic } \\
\text { acids, nitrogen-containing } \\
\text { heterocyclic compounds, } \\
\text { ethanol, alkanes, } \\
\text { and olefins }\end{array}$ & [60] \\
\hline Oak wood & $\begin{array}{c}\text { Moisture } 7-15 \% \text {, ash } 2.0 \% \text {, } \\
\text { cellulose } 38.1 \% \text {, hemicellulose } 23.0 \% \text {, } \\
\text { lignin } 32.0 \% \text {, extract } 6.9 \% \text {, C } 50.2 \% \text {, } \\
\text { H } 7.0 \% \text {, O } 42.8 \%\end{array}$ & $320^{\circ} \mathrm{C}, 15 \mathrm{~min}$ & $1: 5$ & $\mathrm{Fe}$ & $38 \%$ & $\begin{array}{l}\text { Phenols, ketones, } \\
\text { and aliphatic }\end{array}$ & [41] \\
\hline Castor plant & $\begin{array}{c}\text { Moisture } 11.14 \% \text {, ash } 5.40 \% \text {, } \\
\text { volatile } 74.30 \% \text {, fixed carbon } 9.16 \% \text {, } \\
\text { extract } 16.40 \% \text {. cellulose } 38.42 \% \text {, } \\
\text { hemicellulose } 22.40 \% \text {, lignin } 20.20 \%\end{array}$ & $300^{\circ} \mathrm{C}, 60 \mathrm{~min}$ & $1: 6$ & / & $15.9 \%$ & / & [24] \\
\hline Rice straw & $\begin{array}{c}\text { Moisture } 11.8 \% \text {, volatile matter } 79.7 \% \text {, } \\
\text { fixed carbon } 6.3 \% \text {, ash } 10.5 \% \text {, C } 37.8 \% \text {, } \\
\text { H } 5.4 \%, \text { O } 55.8 \%, N \text { N } 0.7 \%, S 0.3 \%\end{array}$ & $280^{\circ} \mathrm{C}, 15 \mathrm{~min}$ & $1: 6$ & $\begin{array}{l}\mathrm{Ni}-\mathrm{Al} / \\
\mathrm{SBA}-15\end{array}$ & $56.6 \%$ & $\begin{array}{l}\text { Aliphatic, phenolic, } \\
\text { and phenol }\end{array}$ & [42] \\
\hline
\end{tabular}

\section{Research Progress on the Effect of Lignocellulosic Tissue Structures on Their Hydrothermal Process}

Lignocellulose is mainly composed of cellulose, hemicellulose, and lignin (they cover more than $95 \%$ of the dry weight of lignocellulose biomass). However, HT bio-oil yields and compositions that are obtained from different types of plants under similar operating conditions vary greatly. It has also been documented that the composition and organizational structure of raw materials also play an important role in the conversion of biomass materials into functional materials [59,60]. Table 1 shows information such as the yield and composition of HT bio-oils from different lignocellulose feedstocks. In this part, we will summarize the influence of plant tissue on bio-oil composition and yield during the hydrothermal process in recent years, including major mode components (namely, cellulose, hemicellulose, and lignin) and real biomass materials.

\subsection{Interaction among Cellulose, Hemicellulose, and Lignin Components}

Some early studies on the model cellulose, hemicellulose, and lignin components and their interactions during the HTL process have been completed. Pedersen, etc. [61] found that during the production of fuel range oxygenates by supercritical hydrothermal liquefaction of lignocellulosic model systems, glucose and xylose demonstrate similar bio-oil yield, and the thought reaction mechanisms for the two model compounds are indistinguishable. An effective hydrogen-to-carbon ratio $\left(\mathrm{H} / \mathrm{C}_{\text {eff }}\right)$ is proposed and expressed as below:

$$
\mathrm{H} / \mathrm{C}_{\text {eff }}=\frac{\mathrm{H}-2 \mathrm{O}}{\mathrm{C}}
$$

Bio-oil yields were correspondingly affected by the elemental composition of the starting materials. For the given model compounds, the higher the $\mathrm{H} / \mathrm{C}_{\text {eff }}$ ratio, the lower the biocrude and biochar yields. However, the chain number may be a latent factor since the higher the $\mathrm{H} / \mathrm{C}_{\text {eff }}$, the lower the carbon chain number for the investigated model compounds.

Lu et al. [62] studied soybean oil, soy protein, microcrystalline cellulose, xylose, lignin, and their mixture as raw materials to simulate real biomass raw materials for the exploration of interaction during the hydrothermal process. When taking a single component as raw material, the bio-oil yield for cellulose, xylose, and lignin is relatively low (less than $10 \mathrm{wt} . \%$ ) under the reaction conditions of $350{ }^{\circ} \mathrm{C}$ and $30 \mathrm{~min}$. The lignin type used in this research is alkali lignin, which can be catalyzed, depredating into phenolic compounds. Those phenolic compounds are more water-soluble and cannot be extracted by dichloromethane, resulting in a decrease in the HT bio-oil yield. HT bio-oil yield obtained from a binary mixture of simulated biomass composition is much higher than that 
calculated by the weighted average yield in each component. Besides, obvious synergy effects in HT bio-oil production are observed in a binary mixture of protein and cellulose, protein and lignin, and cellulose and lignin. Simultaneously, the hydrothermal liquefaction of soybean oil and lignin showed an antagonistic effect on HT bio-oil yield. Based on experimental results, a model is established as below:

$$
Y=\sum_{I} a_{i} X_{i}+\sum_{i} \sum_{j} a_{i j} X_{i} X_{j}
$$

where $\mathrm{Y}$ represents the quantity of interest (wt. \% yield of biocrude, wt. \% C, H, or N in the biocrude). $X_{i}$ is the mass fraction of biochemical constituent $i$ (e.g., lipid, protein, C5 saccharides, lignin) in the feedstock on a dry, ash-free basis. The values of the $a_{i}$ coefficients come directly from the HTL experiments with the individual compounds, and the values of the $\mathrm{a}_{\mathrm{ij}}$ coefficients were obtained by considering the results from the HTL of the binary mixtures. The model could be used to predict the yield, thermal value, and content of $\mathrm{C}, \mathrm{H}$, and $\mathrm{N}$ in hydrothermal liquefaction productions.

Yang and Han et al. [63] take glucose and glutamic acid as biomass material models to investigate the interaction during a hydrothermal process. The study found that when glucose was used only as a feedstock, initial hydrothermal products included furfural, furans, ketones, and acids, which were converted into benzene rings, phenols, and hydrocarbons as the reaction progressed. When only glutamic acid is used as raw material, glutamic acid, through deaminoid and dehydration, forms $\mathrm{NH}_{3}$, arginine, $\mathrm{CO}_{2}$, and amine. Part of the generated $\mathrm{NH}_{3}$ and arginine further reacted to produce amide, coke glutamate, ketones, organic amine compounds, etc. (as shown in Figure 6). As the hydrothermal process goes on, those products are further converted to pyridoxine, esters, phenols, and hydrocarbons. When glucose and glutamate are co-feeds as feedstock, under HZSM-5 catalyst addition, hydrolysis reactions interact, and the content of esters, benzene, pyridine, and icing increases, which improves HT bio-oil quality and yield. The results further show that the effects of the interaction between different components in the process of hydrothermal cannot be ignored during HT bio-oil products distribution and yield.

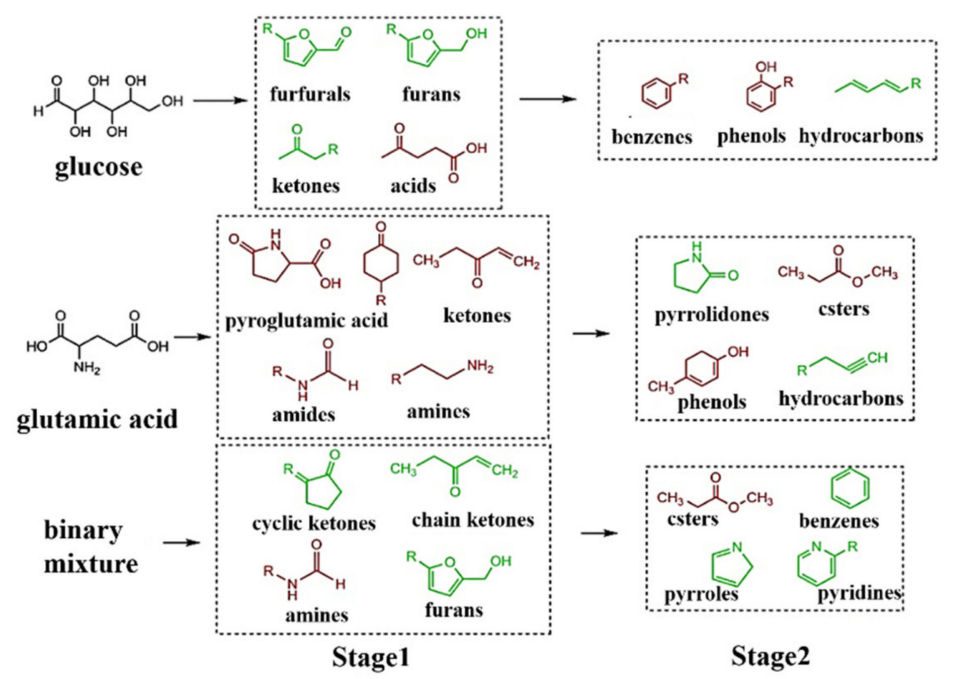

Figure 6. Major reaction profile of the bio-oils produced from the HTL of glucose, glutamic acid, and their binary mixtures with HZSM-5. (Green: the products promoted by HZSM-5; red: the products inhibited by HZSM-5.) (For interpretation of the references to color-in this figure legend, the reader is referred to the web version of this article.). Reprinted with permission from Ref [63]. Copyright 2018 Elsevier.

Yang et al. [64] used a mixture of five model components: xylan (hemicellulose), crystalline cellulose, alkaline lignin, soya protein, and soybean oil to establish a predictive model of HT bio-oil and biochar yields during the HTL process. The reliability of the 
model is verified by using actual raw materials and reaction pathways between two model components, and possible synergies and antagonists are explored (as shown in Figure 7). The results show that interaction among hemicellulose, lipids, and cellulose has synergistic effects on bio-oil production, while the interaction of cellulose and lignin has an antagonistic effect on biochar production. The interaction between carbohydrates and lipids has a great influence on acid, hydrocarbon, and ketone yields. Results can be used to assess the economic value of various biomass for hydrothermal liquefaction, to provide guidance for various biomass feedstocks' co-liquefaction.

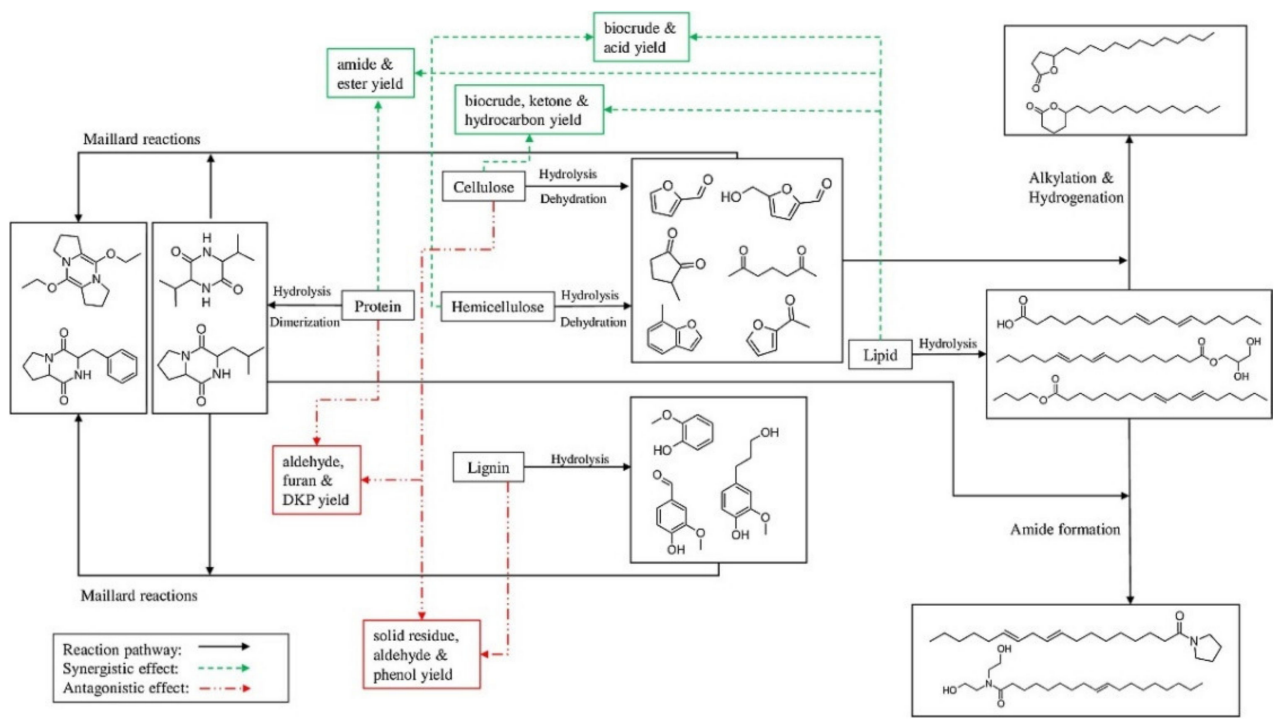

Figure 7. Decomposition pathways of individual model components and related interactions. Reprinted with permission from Ref [64]. Copyright 2018 Elsevier.

Additionally, raised by Yang et al. [65], advanced models have been established for the prediction of product yield in hydrothermal liquefaction via a mixture design of biomass model components coupled with process variables. The model compounds used in this study were represented by soya protein, soybean oil, crystalline cellulose, xylan, and alkaline lignin as the model protein, lipids, polysaccharide, hemicellulose, and lignin. The models could be expressed as:

Biocrude yield $(w t . \%)=19.99 \times X_{1}+9.75 \times X_{2}+1.75 \times X_{3}+97.37 \times X_{4}-33.1 \times X_{1} X_{4}+26.4 \times X_{2} X_{3}+$ $59.8 \times \mathrm{X}_{2} \mathrm{X}_{4}-65.6 \times \mathrm{X}_{3} \mathrm{X}_{4}-25.46 \times \mathrm{X}_{3} \mathrm{X}_{4} \mathrm{X}_{5}-18.93 \times \mathrm{X}_{1} \mathrm{X}_{4} \mathrm{X}_{6}-38.63 \times \mathrm{X}_{1} \mathrm{X}_{4} \mathrm{X}_{7}$

SR yield ^ $0.5(w t . \%)=2.184 \times X_{1}+5.396 \times X_{2}+5.514 \times X_{3}+0.870 \times X_{4}+6.025 \times X_{1} X_{3}-2.051 \times X_{2} X_{3}+$ $4.349 \times \mathrm{X}_{3} \mathrm{X}_{4}+0.455 \times \mathrm{X}_{3} \mathrm{X}_{5}-2.957 \times \mathrm{X}_{1} \mathrm{X}_{2} \mathrm{X}_{5}-3.396 \times \mathrm{X}_{2} \mathrm{X}_{3} \mathrm{X}_{5}-1.838 \times \mathrm{X}_{1} \mathrm{X}_{2} \mathrm{X}_{6}-$ $0.339 \times \mathrm{X}_{2} \mathrm{X}_{7}-0.359 \times \mathrm{X}_{3} \mathrm{X}_{7}$

where $X_{1}, X_{2}, X_{3}, X_{4}$ represent the mass percent of soya protein, saccharide, alkaline lignin, soybean oil; $\mathrm{X}_{5}, \mathrm{X}_{6}, \mathrm{X}_{7}$ represent the temperature $\left({ }^{\circ} \mathrm{C}\right)$, time $(\mathrm{min})$, and mass ratio of water/feedstock. The accuracy of bio-oil and biochar yields prediction models was $94.6 \%$ and $93.2 \%$, respectively, and was verified with simulated and actual raw materials. These models can be used to optimize hydrothermal reaction conditions where the raw material is known, as well as to optimize the composition of the raw material under a given reaction condition. In the experimental design, relatively mild HTL conditions eliminated the interaction between lignin and lipid and protein and lipid, promoting the formation of bio-oil. At the same time, higher hydrothermal temperatures and longer reaction times could promote protein-sugar interaction and sugar and alkaline lignin interaction to reduce the formation of biochar. Similar studies can be found in other literature $[29,66]$.

Déniel et al. [67] chose glucose, xylose, and microcrystalline cellulose to represent carbohydrates, guaiacol and alkali lignin to represent natural lignin, glutamic acid to 
present protein, and linoleic acid to present lipids. Experimental results show that the products are mainly derived from the degradation of individual compounds. Compounds produced in bio-oils and coke are mainly derived from dehydration, dehydration, and shrinkage reactions. Some binary interactions that form bio-oils have been identified, such as the Maillard reaction between carbohydrates and proteins and the interaction between carbohydrates and lipids. In terms of the products' composition, especially when using cellulose models, the hydrothermal liquefaction products components of real biomass can be qualitatively predicted using model components. In fact, the Maillard reaction is considered to be very important during biomass feedstock hydrothermal conversion. Fan, etc., [68] employed lactose, maltose, and lysine as model substances and tested individually and in binary mixtures to evaluate the Maillard reaction network during the HT process. When treated individually, conversion of lysine leads to higher bio-oil yields (5-17 wt.\%) than the model carbohydrates (6-10 wt.\%) during HTL. In mixtures with carbohydrates, the measured bio-oil yields exceeded those obtained from the conversion of the single substances (10-39 wt.\%). Some similar researches could also be found in the published literature [69-71].

Croce et al. [72] used cellulose, bovine serum albumin, and tripalmitin as biomass model components of carbohydrates, proteins, and triglycerides to treat their binary and trinity mixtures under HTL conditions to describe the main reaction pathways of municipal organic waste. As shown in Figure 8, the composition of bio-oil produced in the model components was analyzed and compared with the composition of bio-oil produced by urban organic waste biomass. This ternary mixture can be used as a reliable biomass model to explore reaction mechanisms in biomass treatment, improve the HTL process by modulating the input of organic matter, and obtain high-quality biofuels.

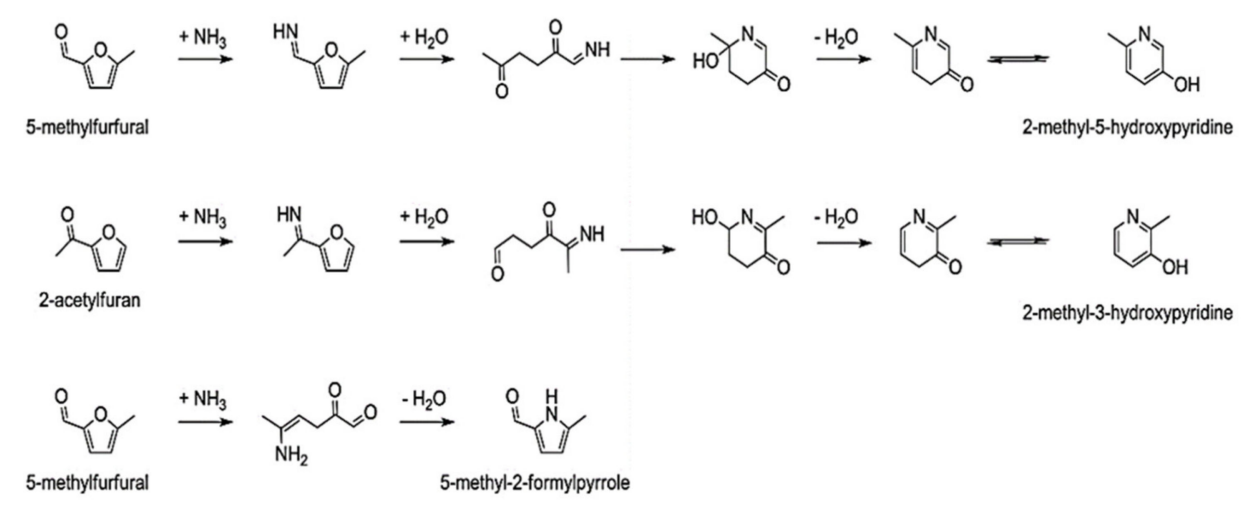

Figure 8. Proposed mechanistic events involved in the formation of some Maillard-type compounds of bio-oil samples obtained after HTL treatment of a cellulose/BSA binary mixture at $300{ }^{\circ} \mathrm{C}$ and $20 \mathrm{~min}$ of reaction time. Reprinted with permission from Ref [72]. Copyright 2017 WILEY-VCH Verlag GmbH \& Co. KgaA.

From the above literature, some facts about the interactions among pure cellulose, hemicellulose, and lignin components could be found. The bio-oil yields and components are correspondingly affected by the elemental composition, effective hydrogen-to-carbon ratio $\left(\mathrm{H} / \mathrm{C}_{\mathrm{eff}}\right)$, and operation parameters (temperature and time). Some less-abundant components (lipids, for example) will play important roles during lignocellulose hydrothermal conversion. Especially, the Maillard reaction could enhance the bio-oil yields when mixed with pure cellulose and hemicellulose during the HT process. As we know and expect, lipids, tannins, pectin, etc., occupy a small space in lignocellulosic raw materials, while the investigations of tannins and pectin with pure cellulose, hemicellulose, and lignin components are limited and needed. 
3.2. Interaction between Cellulose, Hemicellulose, or Lignin Components and Real Lignocellulosic Raw Materials during the Thermal Process

Feng and He et al. [73] studied cellulose and spirulina as feedstock to explore their interaction during the hydrothermal conversion process. Because cellulose is easily converted into small molecules under hydrothermal conditions that are readily water-soluble, the yield of HT bio-oil is very low over a range of $240-340{ }^{\circ} \mathrm{C}$ (as shown in Figure 9). The highest bio-oil yield is obtained at $300^{\circ} \mathrm{C}$. As the temperature further increases, the re-degradation and polymerization reaction occurs, resulting in a decrease in the HT bio-oil yield.

When cellulose and algae are co-feed as raw materials, the co-promotion phenomenon is observed. Firstly, proteomic and cellulose components in algae co-promoted the Maillard reaction and polymerization reaction. As illustrated in Figure 10, furans (a hydrolytic product of cellulose) are more likely to bind to the nitrogen-containing components of algae, thus slowing the trend towards hydrothermal carbon conversion. Although direct evidence that supports the authors' assumptions is limited, it is a side reminder that the interaction of biomass raw materials in the hydrothermal process will greatly affect products distribution and reaction pathways. At the same time, relevant studies show that when adopting mixed biomass species as feedstock, a component of higher $\mathrm{N}$ content, the synergy effect will be more obvious [74].

(a)

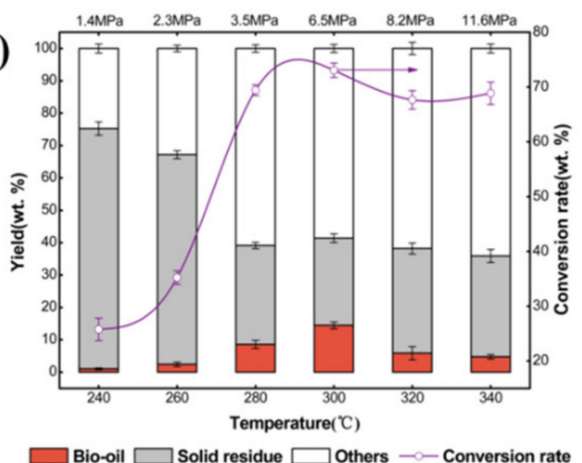

(c)

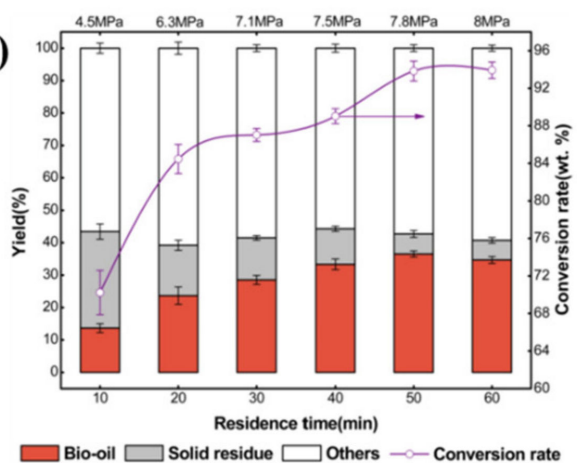

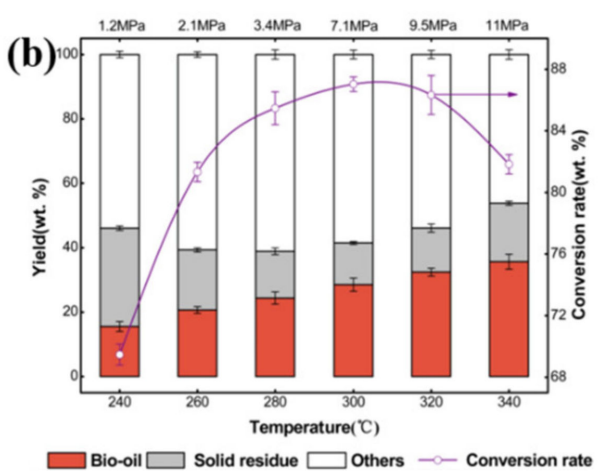

(d)

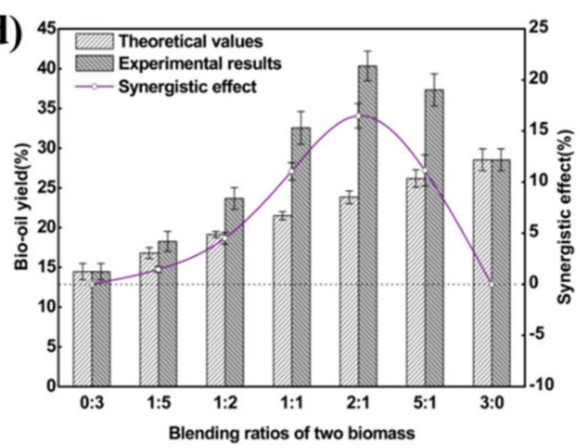

Figure 9. (a) Effect of residence time on HTL product distribution of $\alpha$-Cellulose; (b) effect of temperature on HTL products distribution of Spirulina platensis; (c) effect of blending ratio of Spirulina platensis and $\alpha$-Cellulose on product distribution; (d) synergistic effects of different blending ratios of HTCL of Spirulina platensis and $\alpha$-Cellulose for bio-oil yield. (Temperature of $300{ }^{\circ} \mathrm{C}$, residence time of $30 \mathrm{~min}, 3 \mathrm{~g}$ blending feedstocks, and $30 \mathrm{~mL}$ water.). Reprinted with permission from Ref [73]. Copyright 2019 Elsevier. 


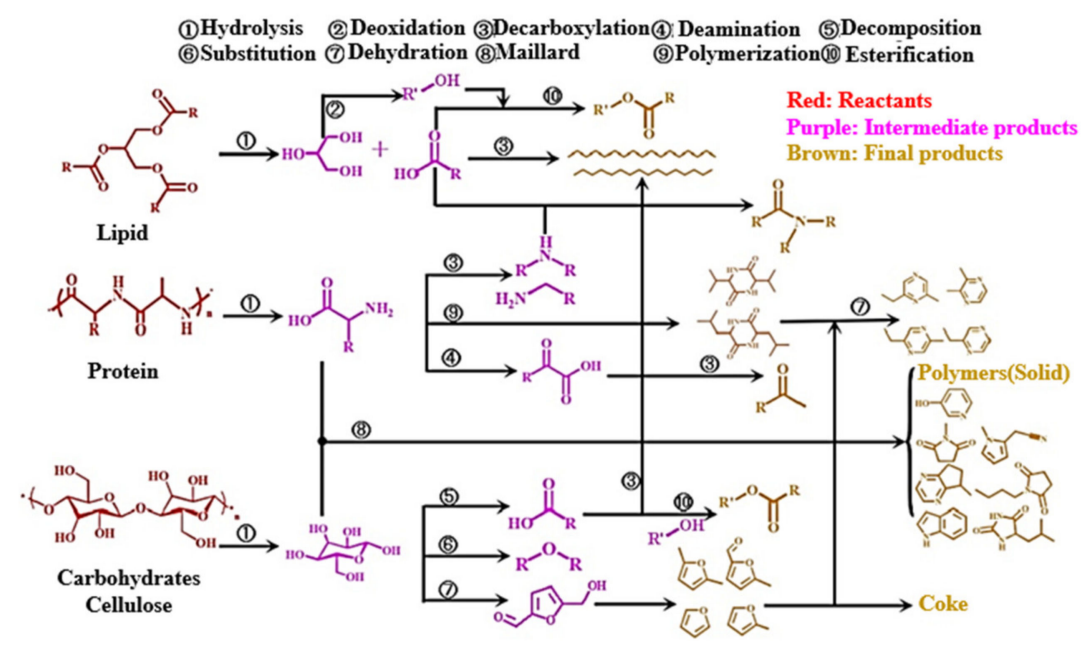

Figure 10. Spirulina platensis and $\alpha$-Cellulose's possible partial pathways to HTCL in subcritical water. Reprinted with permission from Ref [74]. Copyright 2019 Springer Publishing Company.

Chen et al. [66] studied the production of HT bio-oils from spirulina, $\alpha$-cellulose, and lignin. Results showed that the highest bio-oil yield from spirulina and $\alpha$-cellulose HTL was $30 \mathrm{wt.} \%$ and $7.03 \mathrm{wt} . \%$, respectively. When water phase products from the spirulina HTL process are introduced into the HTL system again, significantly higher bio-oil production of spirulina and a-cellulose HTL in the order of $10 \mathrm{wt} . \%$ and $6 \mathrm{wt} . \%$ can be obtained. In the process of HTL, the energy recovery rate of bio-oil is greatly improved by using water-phase product circulation. However, the recycling of water-phase products inhibits the production of bio-oil, which indicates that there is an antagonist reaction between water phase products and lignin. Possible reaction paths of spirulina, $\alpha$-cellulose, and lignin are shown in Figure 11.

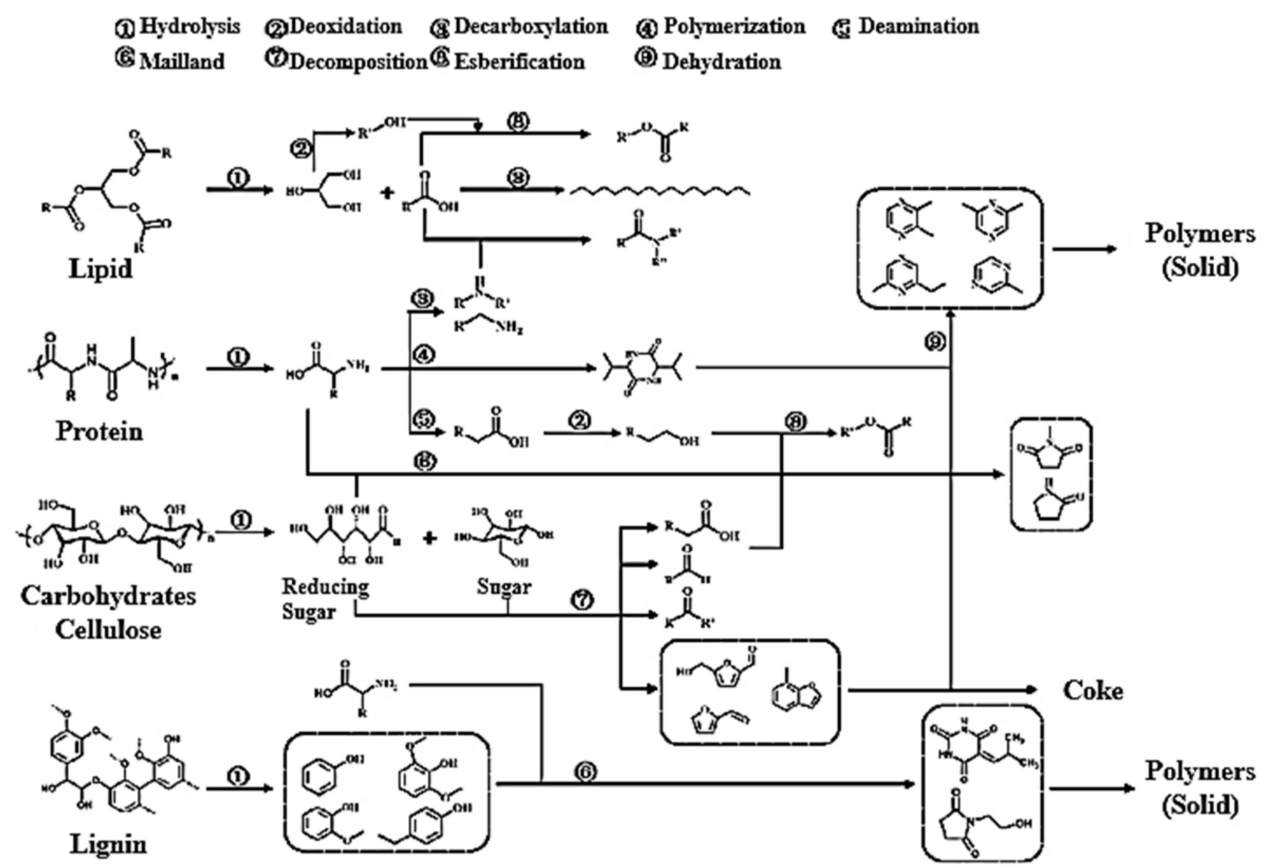

Figure 11. Spirulina platensis, $\alpha$-Cellulose, and lignin's partial possible reaction network to HTL with or without recycled aqueous phase. Reprinted with permission from Ref [66]. Copyright 2019 Elsevier. 
Compared with pure cellulose, hemicellulose, lignin, etc., the interaction between cellulose, hemicellulose, or lignin components and real lignocellulosic raw materials during the thermal process is more complex.

\subsection{Real Biomasses and Their Structure Effects on Their HT Bio-Oil Preparation}

Cao and Zhang et al. [58] have chosen some leaves and branches from eight typical landscape plants as raw materials for the preparation of HT bio-oils at $300{ }^{\circ} \mathrm{C}$ and $0.5 \mathrm{~h}$.

As shown in Figure 12, studies have found little correlation between the HT bio-oil yield and the content of holocellulose in plant component leaves. In the branch, the bio-oil yield and the content of holocellulose were positively correlated, whereas the contents of holocellulose and lignin do not show much difference (as shown in Figure 12). This study shows that the interaction of plant fiber raw materials in the hydrothermal process and their influence on product distribution are very complex. Especially with the co-existence of other components (tannins and pectin, etc.), the yield and distribution of hydrothermal products will be more complex.
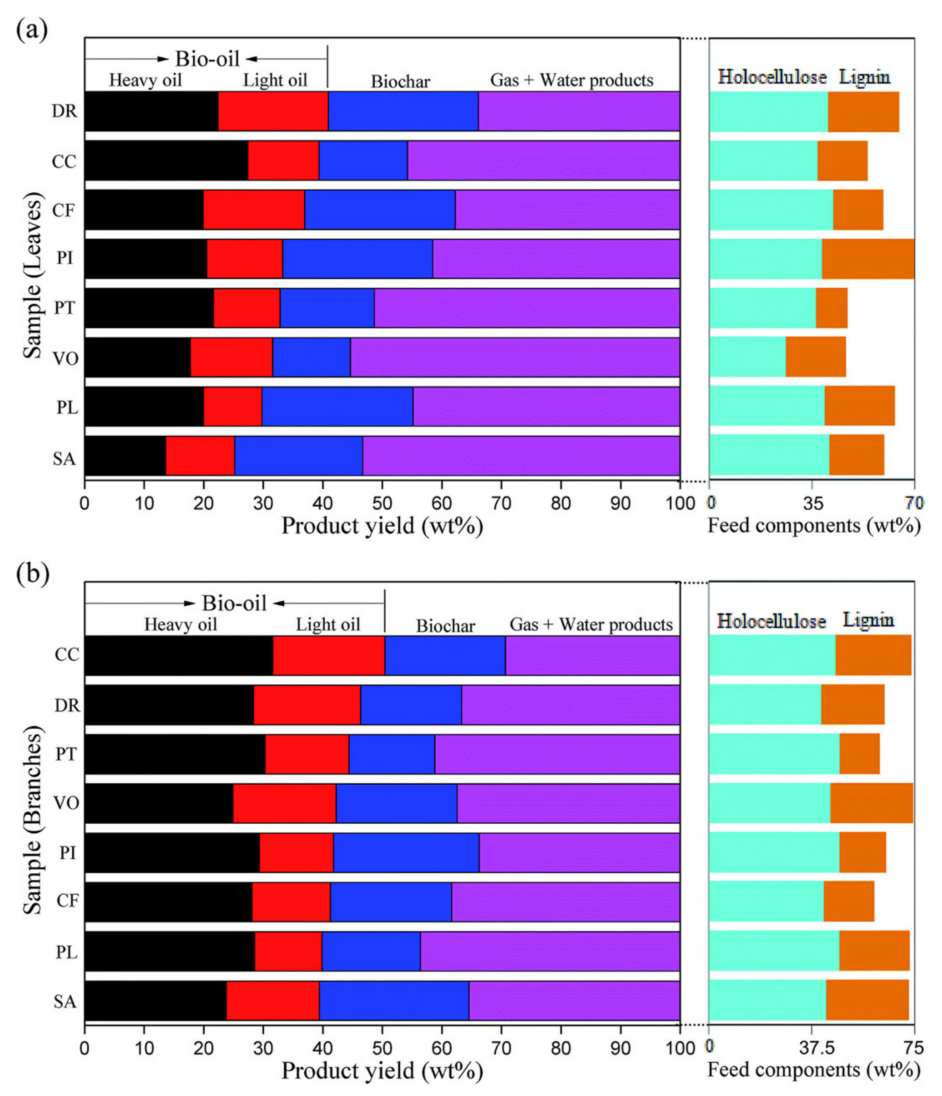

Figure 12. Product yield in HTL of green landscaping wastes. (a) Leaves; (b) branches. Reprinted with permission from Ref [58]. Copyright 2016 RSC Publishing.

Yang and Xu et al. [56] treated spent coffee grounds with HTL under the conditions of $275^{\circ} \mathrm{C}, 10 \mathrm{~min}$ with a liquid-solid ratio of $20: 1$; HT bio-oil yield was as high as $47.3 \%$ (as shown in Figure 13). The high thermal value for obtained HT bio-oil was $31.0 \mathrm{MJ} / \mathrm{Kg}$, a significant increase over raw material $(20.2 \mathrm{MJ} / \mathrm{Kg})$. It shows that high HT bio-oil yield can also be obtained by adjusting operating parameters at lower temperatures. At the same time, the extraction process of caffeine helps to destroy the structure of cell walls and enhance the reaction activity of the main components in a hydrothermal process. 


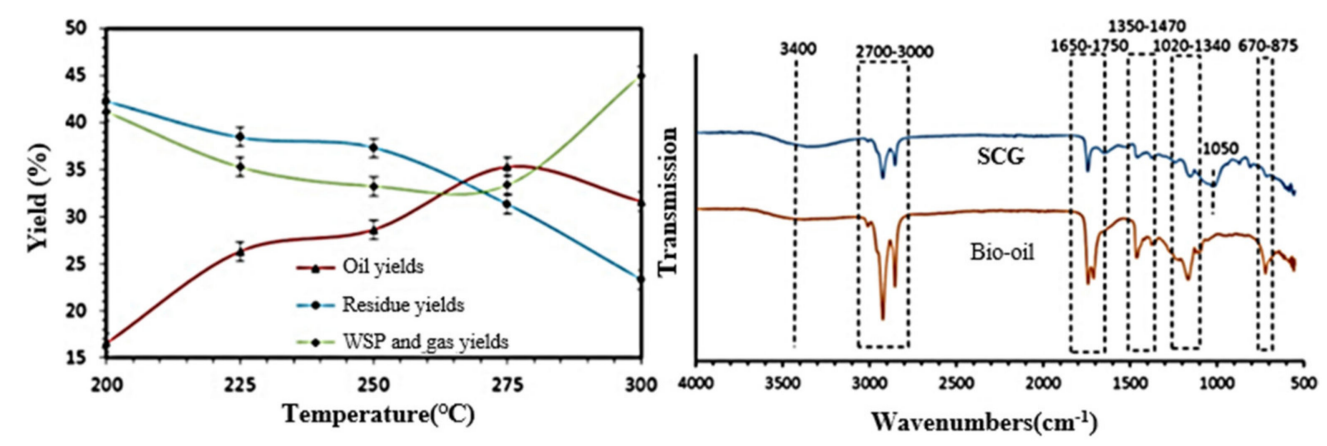

Figure 13. Yields of bio-oil, solid residue, water-soluble product, and gas from the liquefaction at various reaction temperatures (left). FTIR spectrum of spent coffee grounds and the crude biooil derived from SCG liquefaction (right). Reprinted with permission from Ref [56]. Copyright 2016 Elsevier.

In another study, Caprariis et al. [59] studied the relation between HT bio-oil yields and raw material compositions at slightly higher temperatures $\left(280-320^{\circ} \mathrm{C}\right)$ using three different compositions (natural hay, oak wood, and walnut shell, shown in Figure 14). It was found that in all tested temperature ranges, HT bio-oil yield was positively correlated with the lignin content of raw materials and negatively correlated with the content of holocellulose. The authors think that the generated bio-oil during the HTC process was mainly due to some small fragments derived from lignin degradation over a longer reaction time. Cellulose and hemicellulose are more likely to degrade while having sufficient time to further polymerize into carbon-containing components.
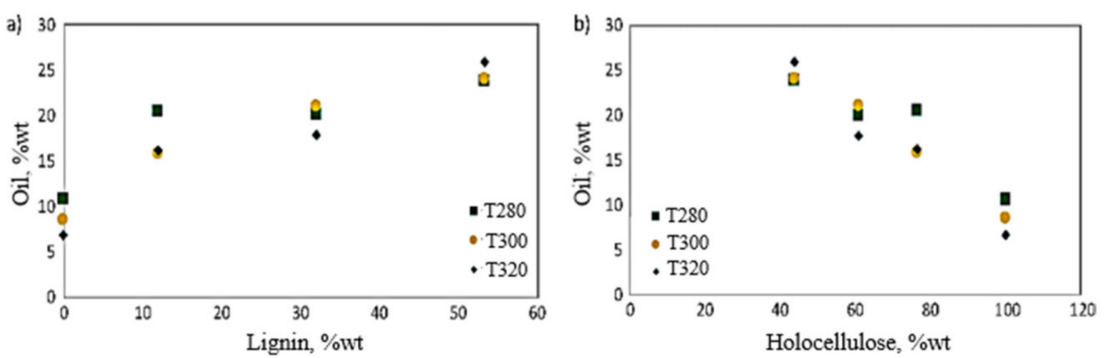

Figure 14. Bio-oil yields as a function of lignin content (a) and holocellulose content (b). Reprinted with permission from Ref [59]. Copyright 2017 Elsevier.

By screening literature, it has been found that the components in raw materials show different reaction pathways. Unfortunately, there are currently fewer detailed comparisons and experiments. Due to the lack of more effective detection methods, reaction paths are mostly based on experience, and more detailed evidence is expected.

Ankit and Nabisab et al. [74] used oil palm fronds as raw materials for hydrothermal conversion at relatively low temperatures $\left(160-260^{\circ} \mathrm{C}\right)$. This study found that palm leaves also had high $\mathrm{HT}$ bio-oil yields under low temperatures $\left(27.3 \mathrm{wt} . \%\right.$ at $160{ }^{\circ} \mathrm{C}$ and 41.9 wt. \% at $260^{\circ} \mathrm{C}$, shown in Figure 15). HT bio-oil composition is mainly composed of phenol, esters, aldehyde, and acids. Compared with raw materials, high thermal value increased from $13.4 \mathrm{MJ} / \mathrm{Kg}$ to $22.413 \mathrm{MJ} / \mathrm{Kg}$. It is worth noting that the leaf did not show a significant advantage over branches from the angle of element analysis and compounds. It is bewildering that oil palm leaves have a high yield in the low-temperature zone, while other biomass raw materials have a low yield in bio-oil in the low-temperature zone. Thus, we still think that the structure of plant raw materials plays a very important role in the hydrothermal transformation process, especially if other group sub-substances (tannins, pectin, etc.) exist. 

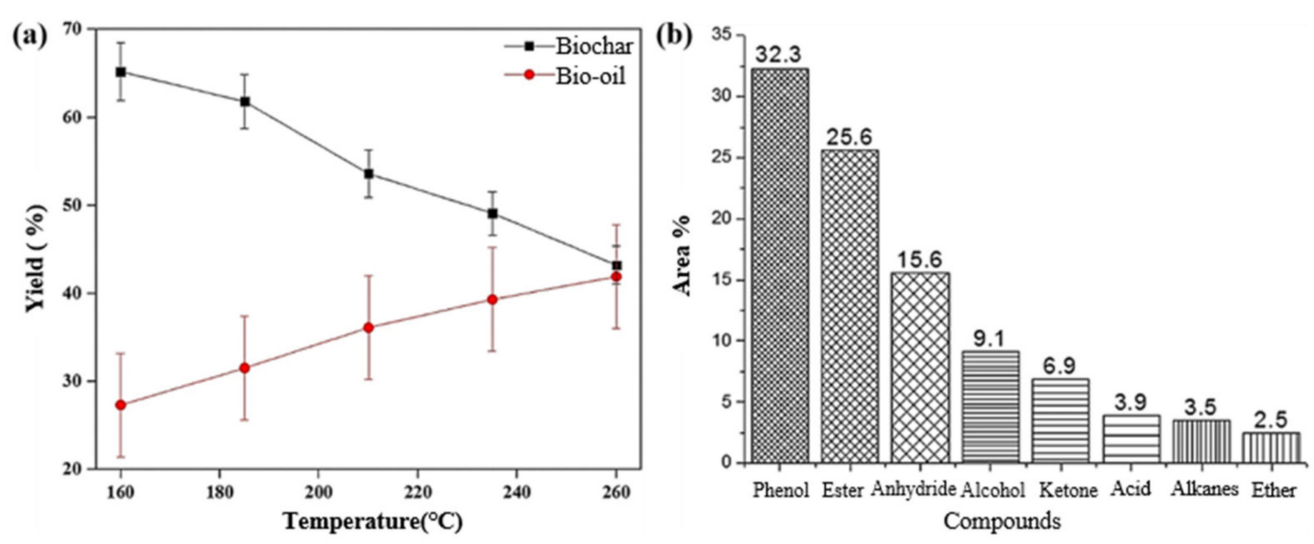

Figure 15. The effect of reaction temperature on the yield percentage of bio-oil and biochar (a) and GC-MS analysis of bio-oil (b). Reprinted with permission from Ref [74]. Copyright 2019 Springer Publishing Company.

Tian and Pei-Gao Duan et al. [60] use four types of straw biomass waste as raw materials (corn straw, CS; peanut straw, PS; soybean straw, SS; and rice straw, RS) to convert them by the hydrothermal conversion method at $320{ }^{\circ} \mathrm{C}$ and $60 \mathrm{~min}$. The HT bio-oils' yield and the straws' composition analysis of the obtained bio-oils are shown in Figure 16.

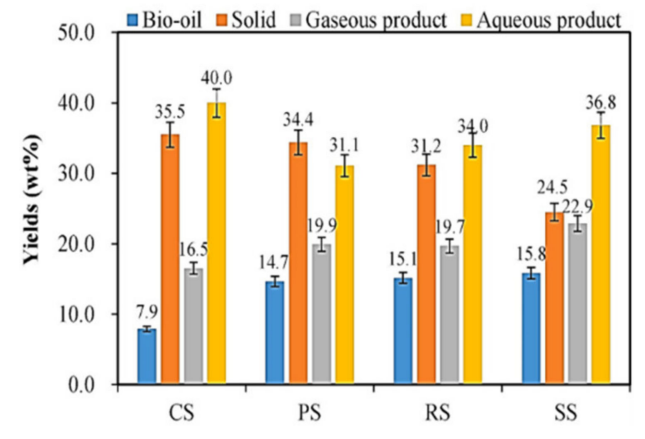

\begin{tabular}{lllll}
\hline & CS bio-oil & SS bio-oil & RS bio-oil & PS bio-oil \\
\hline $\mathrm{C}$ & 72.43 & 73.16 & 72.68 & 72.28 \\
$\mathrm{H}$ & 7.81 & 7.38 & 7.96 & 8.09 \\
$\mathrm{~N}$ & 0.99 & 2.19 & 1.69 & 2.07 \\
$\mathrm{O}$ & 13.29 & 12.68 & 12.40 & 12.26 \\
$\mathrm{~S}$ & 0.28 & 0.22 & 0.33 & 0.24 \\
$\mathrm{H} / \mathrm{C}$ & 1.29 & 1.21 & 1.31 & 1.34 \\
$\mathrm{O} / \mathrm{C}$ & 0.14 & 0.13 & 0.13 & 0.13 \\
$\mathrm{HHV}(\mathrm{M} / \mathrm{kg})$ & 33.24 & 32.98 & 33.70 & 33.78 \\
\hline
\end{tabular}

Figure 16. Yields of product fractions, elemental compositions, and estimated HHVs of the four crop straws. Reprinted with permission from Ref [60]. Copyright 2020 Elsevier.

The present study concluded that the content of cellulose in raw materials and the mass ratio of cellulose to hemicellulose ( $\left.\mathrm{w}_{\text {cellulose }} / \mathrm{w}_{\text {hemicellulose }}\right)$ are important factors in determining HT bio-oil yield. High cellulose content and $\mathrm{w}_{\text {cellulose }} / \mathrm{w}_{\text {hemicellulose }}$ ratio results in high bio-oil yields. SS achieved the highest bio-oil yield among four adopted straws. In addition, this study concluded that the hydrogen bond between cellulose and hemicellulose also affects its reaction activity in hydrothermal reactions, which in turn affects the characteristics of HT bio-oil and product distribution, suggesting that physical properties between raw material components, together with chemical properties, are major factors that determine the production of HT bio-oils.

Wu et al. [43] used poplar as a raw material for hydrothermal liquefaction in the temperature range of $220-280{ }^{\circ} \mathrm{C}$ and took ethyl acetate as a solvent to extract liquid products. The highest bio-oil yield (19.88 wt.\%), the highest bio-oil C content (69.13 wt.\%), and the highest thermal value $(27.97 \mathrm{MJ} / \mathrm{kg})$ were obtained at $260^{\circ} \mathrm{C}$. Because there are fewer aromatics in liquid phase products, the $\mathrm{O} / \mathrm{C}$ and $\mathrm{H} / \mathrm{C}$ of liquid-phase products are relatively high. Combined with GC-MS results, HT bio-oil compounds consist of some phenolic compounds due to the presence of lignin and sugars in biomass feedstock.

Yu et al. [75], using aspen wood as raw material, studied the effects of different metaloxide catalysts ( $\mathrm{NiW} / \mathrm{Al}_{2} \mathrm{O}_{3}$ and $\mathrm{NiMo} / \mathrm{Al}_{2} \mathrm{O}_{3}$ ) on hydrothermal rehydration (Figure 17). High-loaded $\mathrm{NiMo} / \mathrm{Al}_{2} \mathrm{O}_{3}$ catalysts had the best performance, with a bio-oil yield of $71.9 \mathrm{wt} . \%$ and oxygen content of $2.4 \mathrm{wt} . \%$. The GC-MS analysis demonstrates that lignin is 
mainly converted to oxygen-containing polycyclic aromatic hydrocarbons by a decomposing or decomposition reaction during the HTL process. Meanwhile, sugars and lipids are mainly converted to cyclopentanone and fatty acid derivatives.

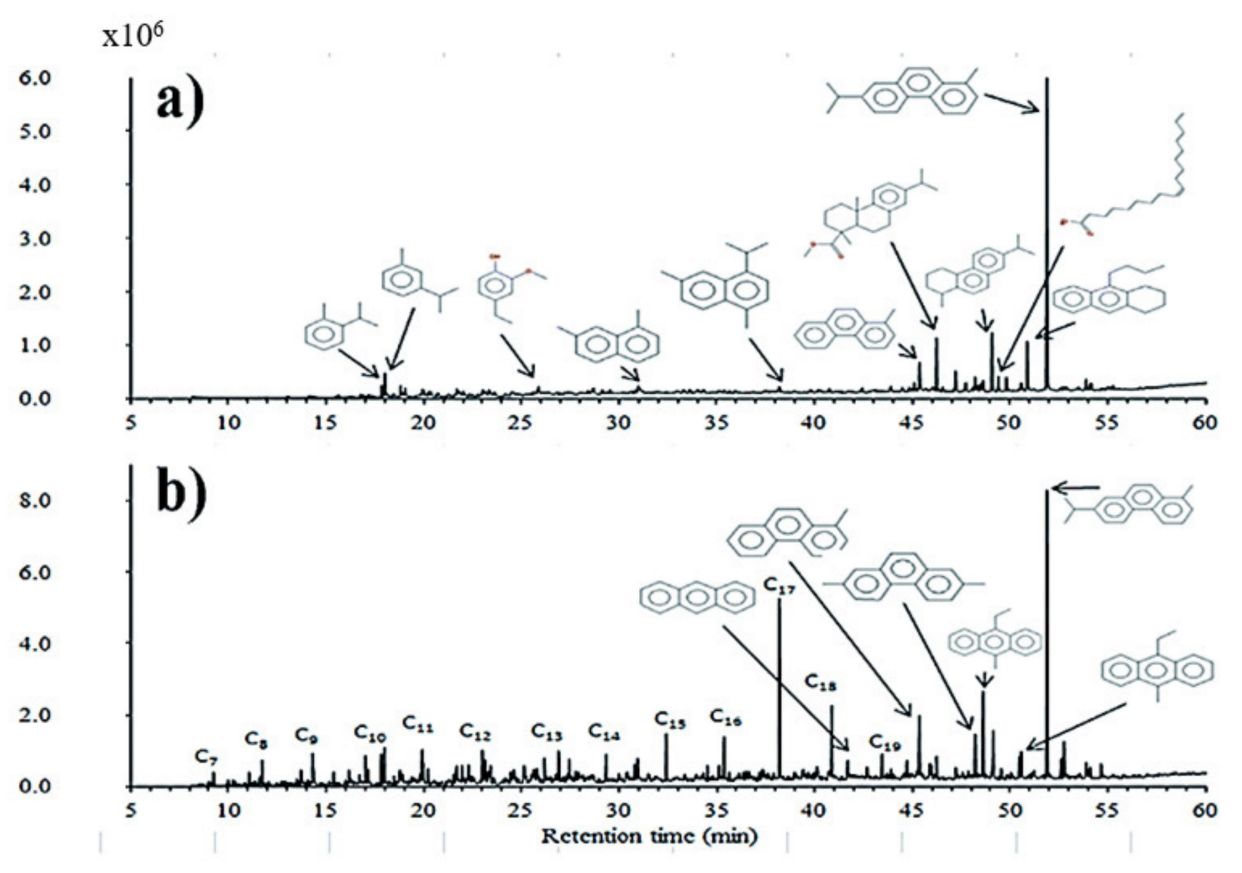

Figure 17. GC-MS total ion chromatograms of (a) bio-crude and (b) hydrotreated bio-oil produced with the NiMo-HL catalyst (initial $\mathrm{H}_{2}$ pressure: 75 bar, reaction time: $2 \mathrm{~h}$, and catalyst loading: 10 wt.\%). Reprinted with permission from Ref [75]. Copyright 2017 RSC Publishing.

Ding et al. [42] examined the effects of different solvents and catalysts (SBA-15, $\mathrm{Ni} / \mathrm{SBA}-15, \mathrm{Al} / \mathrm{SBA}-15, \mathrm{Ni}-\mathrm{Al} / \mathrm{SBA}-15)$ on the HTL process of rice straw. Research demonstrates alcohol-solvents (ethanol and methanol)-extracted bio-oil yields are higher than water. Because of the $\mathrm{Ni}$ and $\mathrm{Al}$ loadings on SBA-15 support, the acid strength of the catalyst increased. Under the Ni-Al/SBA-15 catalyst, the obtained HT bio-oil yields are $44.3 \mathrm{wt} . \%, 56.2 \mathrm{wt} . \%$, and $48.1 \mathrm{wt} . \%$ for water, ethanol, and methanol solvents, respectively. HT bio-oil components are monophenols, phenols, 4-acetylol, 2-methylphenol, 2-methyl-4acetylol, and vanilla aldehyde. Compared with non-catalytic HTL, catalytic HTL promotes hydrogenation and deoxygenation, producing bio-oils with lower molecular weight.

During an HTL process, water can be broken down into $\mathrm{H}^{+}$and $\mathrm{OH}^{-}$; thus, cellulose, hemicellulose, and lignin break down faster than alcohol solvents, producing higher levels of fatty family compounds (2-ethyl ketones, 4-hydroxy-4-methyl). A catalyst can accelerate the $\beta-\mathrm{O}-4$ and $\mathrm{C}-\mathrm{C}$ bond break (mainly in lignin) to obtain more aromatic compounds. Because of the breaking of $\beta-\mathrm{O}-4$ bonds in lignin by $\mathrm{H}^{+}$, more phenolic compounds could be found in lignin-based HT bio-oil. Ethanol is a hydroxyl type solvent that enhances the hydrogen bond strength with oxygen-containing energy groups, and the hydrogen-bondinduced effect enhances the degradation of the lignin and carbohydrate matrix [76].

Yang, etc., [54] took carbohydrate-rich feedstock (sawdust and spent coffee grounds) and co-liquefied it with algal biomass (Chlorella sp. and seaweed) at 270 and $320{ }^{\circ} \mathrm{C}$ with varying mixing ratios of 25:75, 50:50, and 75:25. They found co-liquefaction of sawdust/seaweed exhibited a significantly negative antagonistic effect on the biocrude yield $(-14.8 \%)$. The feedstock mixing ratio (varying biochemical composition of mixture) affected the antagonistic effect, which was reasoned using the knowledge of biomass model components' interactions under liquefaction conditions. It was found that, presumably owing to the Maillard reaction between carbohydrate and protein, sufficient and comparable amounts of carbohydrate and protein in the feedstock mixture were favorable and led to a highly synergetic effect [76,77]. 
As summarized above, real biomasses and their structural effects on their HT biooil preparation are rather complicated. Some predictability models obtained from pure cellulose, hemicellulose, and lignin hydrothermal are unsuitable, which will inspire some more fundamental investigations, including how to evaluate the interaction strength among the real lignocellulose biomass components. Additionally, based on the detailed reaction investigations, it is expected that some research will try to realize high bio-oil yield under mild operation parameters.

\section{Conclusions and Outlook}

Interaction among biomass material components in the process of HTL will greatly affect product distribution and reaction pathways. Cellulose, hemicellulose, lignin, proteins, and lipids have exhibited both synergy and antagonistic effects when adopting different operating conditions and raw material types. Presently, researchers have discussed the relation between HT bio-oil yield and the compositions of raw materials. However, some conclusions are inconsistent and even contrary. Those conclusions include (1) the content of cellulose in raw materials and mass ratio of cellulose to hemicellulose $\left(\mathrm{w}_{\text {cellulose }} / \mathrm{w}_{\text {hemicellulose }}\right)$ is an important factor in determining the yield of HT bio-oils; (2) the chemical and physical properties between raw material components are also important factors affecting the production of HT bio-oils; (3) the used solvents in the hydrothermal process also impact bio-oil yield and composition. General hydrothermal product distributions show the major components within lignocellulose (cellulose, hemicellulose, and lignin) and have certain activities, while high bio-oil yields also require high temperatures. Thus, the explorations of high HT bio-oil yields under mild reaction conditions are expected.

Although some mechanisms have been put forward about the interaction and reaction path of biomass components in the HTL process, unfortunately, fewer detailed pieces of evidence are presented. Meanwhile, due to the lack of more effective detection methods, more direct evidence is limited. The interactions of lignocellulose raw materials in the process of HTL are very complex, especially considering the co-existence of some other components (tannins, pectin, etc.). Some established models that predict HT bio-oil components and yields are not uniform, indicating that some other reasons and considerations may be missed. This fact also should promote researchers to study the HTL process of various biomass materials, examining their performance, yield, and products distribution, which will be important for converting wood fiber biomass into liquid fuels or high-valueadded chemicals. Regarding the production of HT bio-oil under lower temperatures, more microcosmic research could be present in the future that unifies the present experiment's pheromones and turn laboratory achievements into mass production.

Author Contributions: Conceptualization, L.Z.; validation, X.D. and Z.Y.; investigation, L.Z.; writing - original draft preparation, L.Z, X.D., Z.Y. and X.Y.; writing-review and editing, L.Z, and X.G.; project administration, L.Z; funding acquisition, L.Z. All authors have read and agreed to the published version of the manuscript.

Funding: This work was sponsored by the Natural Science Foundation of Xinjiang Uygur Autonomous Region (2021D01B120), the Scientific Research Program of Universities in Xinjiang Uygur Autonomous Region (XJEDU2019Y068), the Research Foundation of China University of PetroleumBeijing at Karamay (YJ2018B02006), and the National College Student Innovation and Entrepreneurship Training Program (202119414003).

Institutional Review Board Statement: Not applicable.

Informed Consent Statement: Not applicable.

Conflicts of Interest: The authors declare no conflict of interest. 


\section{References}

1. Cecilia, J.A.; García-Sancho, C.; Maireles-Torres, P.J.; Luque, R. Industrial Food Waste Valorization: A General Overview. In Biorefinery; Springer: Berlin/Heidelberg, Germany, 2019; pp. 253-277. [CrossRef]

2. Thombs, R.P. Has the relationship between non-fossil fuel energy sources and $\mathrm{CO}_{2}$ emissions changed over time? A cross-national study, 2000-2013. Clim. Change 2018, 148, 481-490. [CrossRef]

3. Liu, D.; Vonwiller, M.; Li, J.; Liu, J.; Szidat, S.; Zhang, Y.; Tian, C.; Chen, Y.; Cheng, Z.; Zhong, G.J.A.; et al. Fossil and Non-fossil Fuel Sources of Organic and Elemental Carbonaceous Aerosol in Beijing, Shanghai, and Guangzhou: Seasonal Carbon Source Variation. Aerosol Air Qual. Res. 2020, 20, 2495-2506. [CrossRef]

4. Zhou, M.; Hu, T. Analysis of carbon emission status under the carbon neutral target in China for Earth's atmospheric balance. IOP Conf. Ser. Earth Environ. Sci. 2021, 804, 042082. [CrossRef]

5. Xie, W.; Guo, W.; Shao, W.; Li, F.; Tang, Z. Environmental and Health Co-Benefits of Coal Regulation under the Carbon Neutral Target: A Case Study in Anhui Province, China. Sustainability 2021, 13, 6498. [CrossRef]

6. Grande, L.; Pedroarena, I.; Korili, S.A.; Gil, A. Hydrothermal Liquefaction of Biomass as One of the Most Promising Alternatives for the Synthesis of Advanced Liquid Biofuels: A Review. Materials 2021, 14, 5286. [CrossRef]

7. Biller, P.; Roth, A. Hydrothermal Liquefaction: A Promising Pathway Towards Renewable Jet Fuel. In Biokerosene: Status and Prospects; Kaltschmitt, M., Neuling, U., Eds.; Springer: Berlin/Heidelberg, Germany, 2018; pp. 607-635.

8. Sharma, R.; Jasrotia, K.; Singh, N.; Ghosh, P.; Srivastava, S.; Sharma, N.R.; Singh, J.; Kanwar, R.; Kumar, A. A Comprehensive Review on Hydrothermal Carbonization of Biomass and its Applications. Chem. Afr. 2020, 3, 1-19. [CrossRef]

9. Ponnusamy, V.K.; Nagappan, S.; Bhosale, R.R.; Lay, C.-H.; Nguyen, D.D.; Pugazhendhi, A.; Chang, S.W.; Kumar, G. Review on sustainable production of biochar through hydrothermal liquefaction: Physico-chemical properties and applications. Bioresour. Technol. 2020, 310, 123414. [CrossRef]

10. Beims, R.F.; Hu, Y.; Shui, H.; Xu, C. Hydrothermal liquefaction of biomass to fuels and value-added chemicals: Products applications and challenges to develop large-scale operations. Biomass Bioenergy 2020, 135, 105510. [CrossRef]

11. Leng, L.; Zhang, W.; Peng, H.; Li, H.; Jiang, S.; Huang, H. Nitrogen in bio-oil produced from hydrothermal liquefaction of biomass: A review. Chem. Eng. J. 2020, 401, 126030. [CrossRef]

12. Hao, B.; Xu, D.; Jiang, G.; Sabri, T.A.; Jing, Z.; Guo, Y. Chemical reactions in the hydrothermal liquefaction of biomass and in the catalytic hydrogenation upgrading of biocrude. Green Chem. 2021, 23, 1562-1583. [CrossRef]

13. De Blasio, C. Notions of Biomass Gasification. In Fundamentals of Biofuels Engineering and Technology; De Blasio, C., Ed.; Springer International Publishing: Cham, Switzerland, 2019; pp. 307-334.

14. Özdenkçi, K.; Prestipino, M.; Björklund-Sänkiaho, M.; Galvagno, A.; De Blasio, C. Alternative energy valorization routes of black liquor by stepwise supercritical water gasification: Effect of process parameters on hydrogen yield and energy efficiency. Renew. Sustain. Energy Rev. 2020, 134, 110146. [CrossRef]

15. Hossain, M.M.; Scott, I.M.; Berruti, F.; Briens, C. Application of Novel Pyrolysis Reactor Technology to Concentrate Bio-oil Components with Antioxidant Activity from Tobacco, Tomato and Coffee Ground Biomass. Waste Biomass Valorization 2018, 9 , 1607-1617. [CrossRef]

16. Wang, H.; Ma, Z.; Chen, X.; Hasan, M.R.M. Preparation process of bio-oil and bio-asphalt, their performance, and the application of bio-asphalt: A comprehensive review. J. Traffic Transp. Eng. 2020, 7, 137-151. [CrossRef]

17. Zhang, Z.; Macquarrie, D.J.; De Bruyn, M.; Budarin, V.L.; Hunt, A.J.; Gronnow, M.J.; Fan, J.; Shuttleworth, P.S.; Clark, J.H.; Matharu, A.S. Low-temperature microwave-assisted pyrolysis of waste office paper and the application of bio-oil as an Al adhesive. Green Chem. 2015, 17, 260-270. [CrossRef]

18. De Blasio, C. Integrated Biorefinery Concepts. In Fundamentals of Biofuels Engineering and Technology; Springer International Publishing: Cham, Switzerland, 2019; pp. 155-171.

19. Ozdenkci, K.; De Blasio, C.; Muddassar, H.R.; Melin, K.; Oinas, P.; Koskinen, J.; Sarwar, G.; Järvinen, M. A novel biorefinery integration concept for lignocellulosic biomass. Energy Convers. Manag. 2017, 149, 974-987. [CrossRef]

20. Ahamed, T.S.; Anto, S.; Mathimani, T.; Brindhadevi, K.; Pugazhendhi, A. Upgrading of bio-oil from thermochemical conversion of various biomass-Mechanism, challenges and opportunities. Fuel 2021, 287, 119329. [CrossRef]

21. Sahoo, A.; Saini, K.; Jindal, M.; Bhaskar, T.; Pant, K.K. Co-Hydrothermal Liquefaction of algal and lignocellulosic biomass: Status and perspectives. Bioresour. Technol. 2021, 342, 125948. [CrossRef]

22. Cheng, F.; Cui, Z.; Chen, L.; Jarvis, J.; Paz, N.; Schaub, T.; Nirmalakhandan, N.; Brewer, C.E. Hydrothermal liquefaction of highand low-lipid algae: Bio-crude oil chemistry. Appl. Energy 2017, 206, 278-292. [CrossRef]

23. Chen, H.; Luo, G.; Zhang, S. Hydrothermal Liquefaction of Lignocellulosic Biomass for Bioenergy Production. In Sustainable Resource Management: Technologies for Recovery and Reuse of Energy and Waste Materials; John Wiley \& Sons: Hoboken, NJ, USA, 2021.

24. Kaur, R.; Gera, P.; Jha, M.K.; Bhaskar, T. Optimization of process parameters for hydrothermal conversion of castor residue. Sci. Total Environ. 2019, 686, 641-647. [CrossRef]

25. Çolak, U.; Durak, H.; Genel, S. Hydrothermal liquefaction of Syrian mesquite (Prosopis farcta): Effects of operating parameters on product yields and characterization by different analysis methods. J. Supercrit. Fluids 2018, 140, 53-61. [CrossRef]

26. Wang, X.; Xie, X.-A.; Sun, J.; Liao, W. Effects of liquefaction parameters of cellulose in supercritical solvents of methanol, ethanol and acetone on products yield and compositions. Bioresour. Technol. 2019, 275, 123-129. [CrossRef] [PubMed] 
27. Yücedağ, E.; Durak, H. Bio-oil and bio-char from lactuca scariola: Significance of catalyst and temperature for assessing yield and quality of pyrolysis. Energy Sources Part A Recovery Util. Environ. Eff. 2019, 1-14. [CrossRef]

28. Rachel-Tang, D.Y.; Islam, A.; Taufiq-Yap, Y.H. Bio-oil production via catalytic solvolysis of biomass. RSC Adv. 2017, 7, 7820-7830. [CrossRef]

29. Remón, J.; Randall, J.; Budarin, V.L.; Clark, J.H. Production of bio-fuels and chemicals by microwave-assisted, catalytic, hydrothermal liquefaction (MAC-HTL) of a mixture of pine and spruce biomass. Green Chem. 2019, 21, 284-299. [CrossRef]

30. Yang, J.; Niu, H.; Corscadden, K.; He, Q.; Zhou, N. MW-assisted hydrothermal liquefaction of spent coffee grounds. Can. J. Chem. Eng. 2021, 1, 1-10. [CrossRef]

31. Gao, Y.; Remón, J.; Matharu, A.S. Microwave-assisted hydrothermal treatments for biomass valorisation: A critical review. Green Chem. 2021, 23, 3502-3525. [CrossRef]

32. Siddiqui, M.T.H.; Chan, F.L.; Nizamuddin, S.; Baloch, H.A.; Kundu, S.; Czajka, M.; Griffin, G.; Tanksale, A.; Shah, K.; Srinivasan, M. Comparative study of microwave and conventional solvothermal synthesis for magnetic carbon nanocomposites and bio-oil from rice husk. J. Environ. Chem. Eng. 2019, 7, 103266. [CrossRef]

33. Yang, C.; Wang, S.; Ren, M.; Li, Y.; Song, W. Hydrothermal Liquefaction of an Animal Carcass for Biocrude Oil. Energy Fuels 2019, 33, 11302-11309. [CrossRef]

34. Montesantos, N.; Maschietti, M. Supercritical Carbon Dioxide Extraction of Lignocellulosic Bio-Oils: The Potential of Fuel Upgrading and Chemical Recovery. Energies 2020, 13, 1600. [CrossRef]

35. Pang, S. Advances in thermochemical conversion of woody biomass to energy, fuels and chemicals. Biotechnol. Adv. 2019, 37, 589-597. [CrossRef]

36. Anastasakis, K.; Biller, P.; Madsen, R.B.; Glasius, M.; Johannsen, I. Continuous Hydrothermal Liquefaction of Biomass in a Novel Pilot Plant with Heat Recovery and Hydraulic Oscillation. Energies 2018, 11, 2695. [CrossRef]

37. Lane, J. The Silver in Silva: The Story of Steeper Energy and SGF's \$59M Advanced Biofuels Project in Norway. Available online: http: / / www.biofuelsdigest.com/bdigest/2018/01/16/the-silver-in-silva-thestory-of-steeper-energys-59m-advancedbiofuels-project-in-norway (accessed on 17 April 2018).

38. Muradel Pty Ltd. Corporate Website. Available online: http://www.muradel.com.au (accessed on 26 April 2018).

39. Chinnasamy, S.; Bhaskar, S.; Nallasivam, J.; Kumar Ratha, S.; Lewis, D.M.; Meenakshisundaram, A.; Lavanya, M.; Selvavathi, C. Method for Processing Algae, Carbonaceous Feedstocks, and Their Mixtures to Biocrude and Its Conversion into Biofuel Products. U.S. Patent 2017/0198223 A1, 13 July 2017.

40. Xu, Y.-H.; Li, M.-F. Hydrothermal liquefaction of lignocellulose for value-added products: Mechanism, parameter and production application. Bioresour. Technol. 2021, 342, 126035. [CrossRef]

41. De Caprariis, B.; Bavasso, I.; Bracciale, M.P.; Damizia, M.; De Filippis, P.; Scarsella, M. Enhanced bio-crude yield and quality by reductive hydrothermal liquefaction of oak wood biomass: Effect of iron addition. J. Anal. Appl. Pyrolysis 2019, 139, 123-130. [CrossRef]

42. Ding, Y.-J.; Zhao, C.-X.; Liu, Z.-C. Catalytic hydrothermal liquefaction of rice straw for production of monomers phenol over metal supported mesoporous catalyst. Bioresour. Technol. 2019, 294, 122097. [CrossRef]

43. Wu, X.-F.; Zhou, Q.; Li, M.-F.; Li, S.-X.; Bian, J.; Peng, F. Conversion of poplar into bio-oil via subcritical hydrothermal liquefaction: Structure and antioxidant capacity. Bioresour. Technol. 2018, 270, 216-222. [CrossRef] [PubMed]

44. Mishra, S.; Mohanty, K. Co-HTL of domestic sewage sludge and wastewater treatment derived microalgal biomass-An integrated biorefinery approach for sustainable biocrude production. Energy Convers. Manag. 2020, 204, 112312. [CrossRef]

45. Lozano, E.M.; Petersen, S.B.; Paulsen, M.M.; Rosendahl, L.A.; Pedersen, T.H. Techno-economic evaluation of carbon capture via physical absorption from HTL gas phase derived from woody biomass and sewage sludge. Energy Convers. Manag. X 2021, 11, 100089. [CrossRef]

46. Cuello, C.; Marchand, P.; Laurans, F.; Grand-Perret, C.; Lainé-Prade, V.; Pilate, G.; Déjardin, A. ATR-FTIR Microspectroscopy Brings a Novel Insight into the Study of Cell Wall Chemistry at the Cellular Level. Front. Plant Sci. 2020, 11, 105. [CrossRef]

47. Marmont, L.S.; Bernhardt, T.G. A conserved subcomplex within the bacterial cytokinetic ring activates cell wall synthesis by the FtsW-FtsI synthase. Proc. Natl. Acad. Sci. USA 2020, 117, 23879-23885. [CrossRef] [PubMed]

48. Maaß, M.-C.; Saleh, S.; Militz, H.; Volkert, C.A. The Structural Origins of Wood Cell Wall Toughness. Adv. Mater. 2020, $32,1907693$. [CrossRef]

49. Mika, L.T.; Cséfalvay, E.; Nemeth, A. Catalytic Conversion of Carbohydrates to Initial Platform Chemicals: Chemistry and Sustainability. Chem. Rev. 2018, 118, 505-613. [CrossRef] [PubMed]

50. Gírio, F.M.; Fonseca, C.; Carvalheiro, F.; Duarte, L.C.; Marques, S.; Lukasik, R. Hemicelluloses for fuel ethanol: A review. Bioresour. Technol. 2010, 101, 4775-4800. [CrossRef]

51. Kobayashi, H.; Fukuoka, A. Development of Solid Catalyst-Solid Substrate Reactions for Efficient Utilization of Biomass. Bull. Chem. Soc. Jpn. 2018, 91, 29-43. [CrossRef]

52. Usman, M.; Chen, H.; Chen, K.; Ren, S.; Clark, J.H.; Fan, J.; Luo, G.; Zhang, S. Characterization and utilization of aqueous products from hydrothermal conversion of biomass for bio-oil and hydro-char production: A review. Green Chem. 2019, 21, 1553-1572. [CrossRef]

53. Zhang, L.; Tan, J.; Xing, G.; Dou, X.; Guo, X. Cotton stalk-derived hydrothermal carbon for methylene blue dye removal: Investigation of the raw material plant tissues. Bioresour. Bioprocess. 2021, 8, 10. [CrossRef] 
54. Yang, J.; He, Q.S.; Niu, H.; Astatkie, T.; Corscadden, K.; Shi, R. Statistical Clarification of the Hydrothermal Co-Liquefaction Effect and Investigation on the Influence of Process Variables on the Co-Liquefaction Effect. Ind. Eng. Chem. Res. 2020, 59, $2839-2848$. [CrossRef]

55. Sipponen, M.H.; Özdenkci, K.; Muddassar, H.R.; Melin, K.; Golam, S.; Oinas, P. Hydrothermal Liquefaction of Softwood: Selective Chemical Production Under Oxidative Conditions. ACS Sustain. Chem. Eng. 2016, 4, 3978-3984. [CrossRef]

56. Yang, L.; Nazari, L.; Yuan, Z.; Corscadden, K.; Xu, C.C. Hydrothermal liquefaction of spent coffee grounds in water medium for bio-oil production. Biomass Bioenergy 2016, 86, 191-198. [CrossRef]

57. Singh, R.; Balagurumurthy, B.; Prakash, A.; Bhaskar, T. Catalytic hydrothermal liquefaction of water hyacinth. Bioresour. Technol. 2015, 178, 157-165. [CrossRef] [PubMed]

58. Cao, L.; Luo, G.; Zhang, S.; Chen, J. Bio-oil production from eight selected green landscaping wastes through hydrothermal liquefaction. RSC Adv. 2016, 6, 15260-15270. [CrossRef]

59. De Caprariis, B.; De Filippis, P.; Petrullo, A.; Scarsella, M. Hydrothermal liquefaction of biomass: Influence of temperature and biomass composition on the bio-oil production. Fuel 2017, 208, 618-625. [CrossRef]

60. Tian, Y.; Wang, F.; Djandja, J.O.; Zhang, S.-L.; Xu, Y.-P.; Duan, P.-G. Hydrothermal liquefaction of crop straws: Effect of feedstock composition. Fuel 2020, 265, 116946. [CrossRef]

61. Pedersen, T.H.; Rosendahl, L.A. Production of fuel range oxygenates by supercritical hydrothermal liquefaction of lignocellulosic model systems. Biomass Bioenergy 2015, 83, 206-215. [CrossRef]

62. Lu, J.; Liu, Z.; Zhang, Y.; Savage, P.E. Synergistic and Antagonistic Interactions during Hydrothermal Liquefaction of Soybean Oil, Soy Protein, Cellulose, Xylose, and Lignin. ACS Sustain. Chem. Eng. 2018, 6, 14501-14509. [CrossRef]

63. Yang, W.; Wang, Z.; Song, S.; Chen, H.; Wang, X.; Cheng, J.; Sun, R.; Han, J. Understanding catalytic mechanisms of HZSM-5 in hydrothermal liquefaction of algae through model components: Glucose and glutamic acid. Biomass Bioenergy 2019, 130, 105356. [CrossRef]

64. Yang, J.; Niu, H.; Corscadden, K.; Astatkie, T. Hydrothermal liquefaction of biomass model components for product yield prediction and reaction pathways exploration. Appl. Energy 2018, 228, 1618-1628. [CrossRef]

65. Yang, J.; Corscadden, K.; Niu, H.; Lin, J.; Astatkie, T. Advanced models for the prediction of product yield in hydrothermal liquefaction via a mixture design of biomass model components coupled with process variables. Appl. Energy 2019, 233, 906-915. [CrossRef]

66. Chen, H.; He, Z.; Zhang, B.; Feng, H.; Kandasamy, S.; Wang, B. Effects of the aqueous phase recycling on bio-oil yield in hydrothermal liquefaction of Spirulina Platensis, $\alpha$-cellulose, and lignin. Energy 2019, 179, 1103-1113. [CrossRef]

67. Déniel, M.; Haarlemmer, G.; Roubaud, A.; Weiss-Hortala, E.; Fages, J. Hydrothermal liquefaction of blackcurrant pomace and model molecules: Understanding of reaction mechanisms. Sustain. Energy Fuels 2017, 1, 555-582. [CrossRef]

68. Fan, Y.; Hornung, U.; Dahmen, N.; Kruse, A. Hydrothermal liquefaction of protein-containing biomass: Study of model compounds for Maillard reactions. Biomass Convers. Biorefinery 2018, 8, 909-923. [CrossRef]

69. Yang, J.; He, Q.; Niu, H.; Dalai, A.; Corscadden, K.; Zhou, N. Microwave-assisted hydrothermal liquefaction of biomass model components and comparison with conventional heating. Fuel 2020, 277, 118202. [CrossRef]

70. Qiu, Y.; Aierzhati, A.; Cheng, J.; Guo, H.; Yang, W.; Zhang, Y. Biocrude Oil Production through the Maillard Reaction between Leucine and Glucose during Hydrothermal Liquefaction. Energy Fuels 2019, 33, 8758-8765. [CrossRef]

71. Fan, Y.; Hornung, U.; Raffelt, K.; Dahmen, N. The influence of lipids on the fate of nitrogen during hydrothermal liquefaction of protein-containing biomass. J. Anal. Appl. Pyrolysis 2020, 147, 104798. [CrossRef]

72. Croce, A.; Battistel, E.; Chiaberge, S.; Spera, S.; De Angelis, F.; Reale, S. A Model Study to Unravel the Complexity of Bio-Oil from Organic Wastes. ChemSusChem 2017, 10, 171-181. [CrossRef] [PubMed]

73. Feng, H.; He, Z.; Zhang, B.; Chen, H.; Wang, Q.; Kandasamy, S. Synergistic bio-oil production from hydrothermal co-liquefaction of Spirulina platensis and $\alpha$-Cellulose. Energy 2019, 174, 1283-1291. [CrossRef]

74. Jadhav, A.; Ahmed, I.; Baloch, A.G.; Jadhav, H.; Nizamuddin, S.; Siddiqui, M.T.H.; Baloch, H.A.; Qureshi, S.S.; Mubarak, N.M. Utilization of oil palm fronds for bio-oil and bio-char production using hydrothermal liquefaction technology. Biomass Convers. Biorefinery 2019, 11, 1465-1473. [CrossRef]

75. Yu, J.; Biller, P.; Mamahkel, A.; Klemmer, M.; Becker, J.; Glasius, M.; Iversen, B.B. Catalytic hydrotreatment of bio-crude produced from the hydrothermal liquefaction of aspen wood: A catalyst screening and parameter optimization study. Sustain. Energy Fuels 2017, 1, 832-841. [CrossRef]

76. Ellersdorfer, M. Hydrothermal co-liquefaction of chlorella vulgaris with food processing residues, green waste and sewage sludge. Biomass Bioenergy 2020, 142, 105796. [CrossRef]

77. Liu, Q.; Xu, R.; Yan, C.; Han, L.; Lei, H.; Ruan, R.; Zhang, X. Fast hydrothermal co-liquefaction of corn stover and cow manure for biocrude and hydrochar production. Bioresour. Technol. 2021, 340, 125630. [CrossRef] 